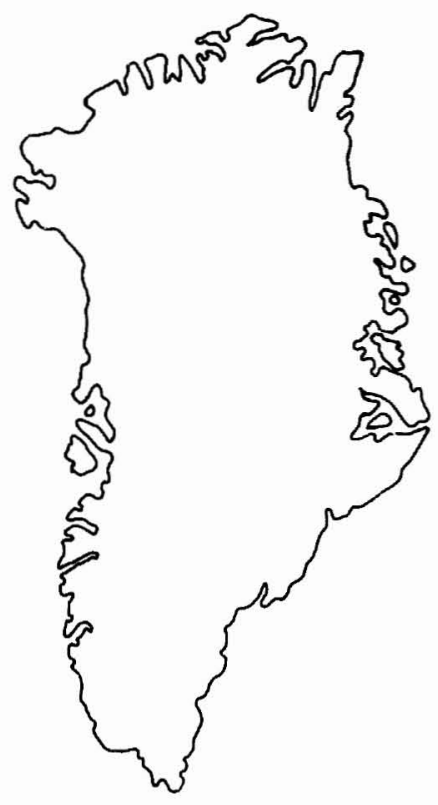

\title{
Stratigraphy and depositional history of the Upper Palaeozoic and Triassic sediments in the Wandel Sea Basin, central and eastern North Greenland
}

\author{
Lars Stemmerik and Eckart Håkansson
}

\begin{abstract}
A lithostratigraphic scheme is erected for the Lower Carboniferous to Triassic sediments of the Wandel Sea Basin, from Lockwood $\varnothing$ in the west to Holm Land in the east. The scheme is based on the subdivision into the Upper Carboniferous - Lower Permian Mallemuk Mountain Group and the Upper Permian - Triassic Trolle Land Group. In addition the Upper Carboniferous Sortebakker Formation and the Upper Permian Kap Kraka Formation are defined.

Three formations and four members are included in the Mallemuk Mountain Group. Lithostratigraphic units include: Kap Jungersen Formation (new) composed of interbedded limestones, sandstones and shales with minor gypsum - early Moscovian; Foldedal Formation composed of interbedded limestones and sandstones - late Moscovian to late Gzhelian; Kim Fjelde Formation composed of well bedded limestones - late Gzhelian to Kungurian.

The Trolle Land Group includes three formations: Midnatfjeld Formation composed of dark shales, sandstones and limestones - Late Permian; Parish Bjerg Formation composed of a basal conglomeratic sandstone overlain by shales and sandstones - ?Early Triassic (Scythian); Dunken Formation composed of dark shales and sandstones - Triassic (Scythian-Anisian).

The Sortebakker Formation (new) is composed of interbedded sandstones, shales and minor coal of floodplain origin. The age is Early Carboniferous. The Kap Kraka Formation (new) includes poorly known hematitic sandstones, conglomerates and shales of Late Permian age.
\end{abstract}

L. S., Geological Survey of Greenland, Øster Voldgade 10, DK-1350 Copenhagen K, Denmark.

E. H., Institute of Historical Geology and Palaeontology, Øster Voldgade 10, DK-1350 Copenhagen K, Denmark.

\section{Introduction}

The lithostratigraphic scheme proposed here encompasses all sediments of Carboniferous to Triassic age in the Wandel Sea Basin from Lockwood Ø in the far west to Holm Land in the south-east (fig. 1). The stratigraphic scheme is a result of the fieldwork carried out in 1978 and 1980 in the Geological Survey of Greenland's mapping programme in central and eastern North Greenland (Henriksen, 1981).

A preliminary lithostratigraphic scheme was erected by Håkansson (1979) after mapping the sequence in eastern Peary Land. The present embracive scheme is based on the subdivision proposed by Håkansson (1979) into the Upper Carboniferous - Lower Permian Mallemuk Mountain Group and the Upper Permian - Triassic Trolle Land Group (fig. 2). Major additions to the scheme of Håkansson (1979) are the introduction of one new formation, and four new members in the Mallemuk Mountain Group (fig. 2). Furthermore, the Sortebakker Formation (fig. 2) is erected to cover a lower Carboniferous sequence of continental sediments underlying the Mallemuk Mountain Group in southern Holm Land and the Kap Kraka Formation (fig. 2) is introduced to include an Upper Permian continental sequence in the Harder Fjord Fault Zone near Midtkap (fig. 1). 


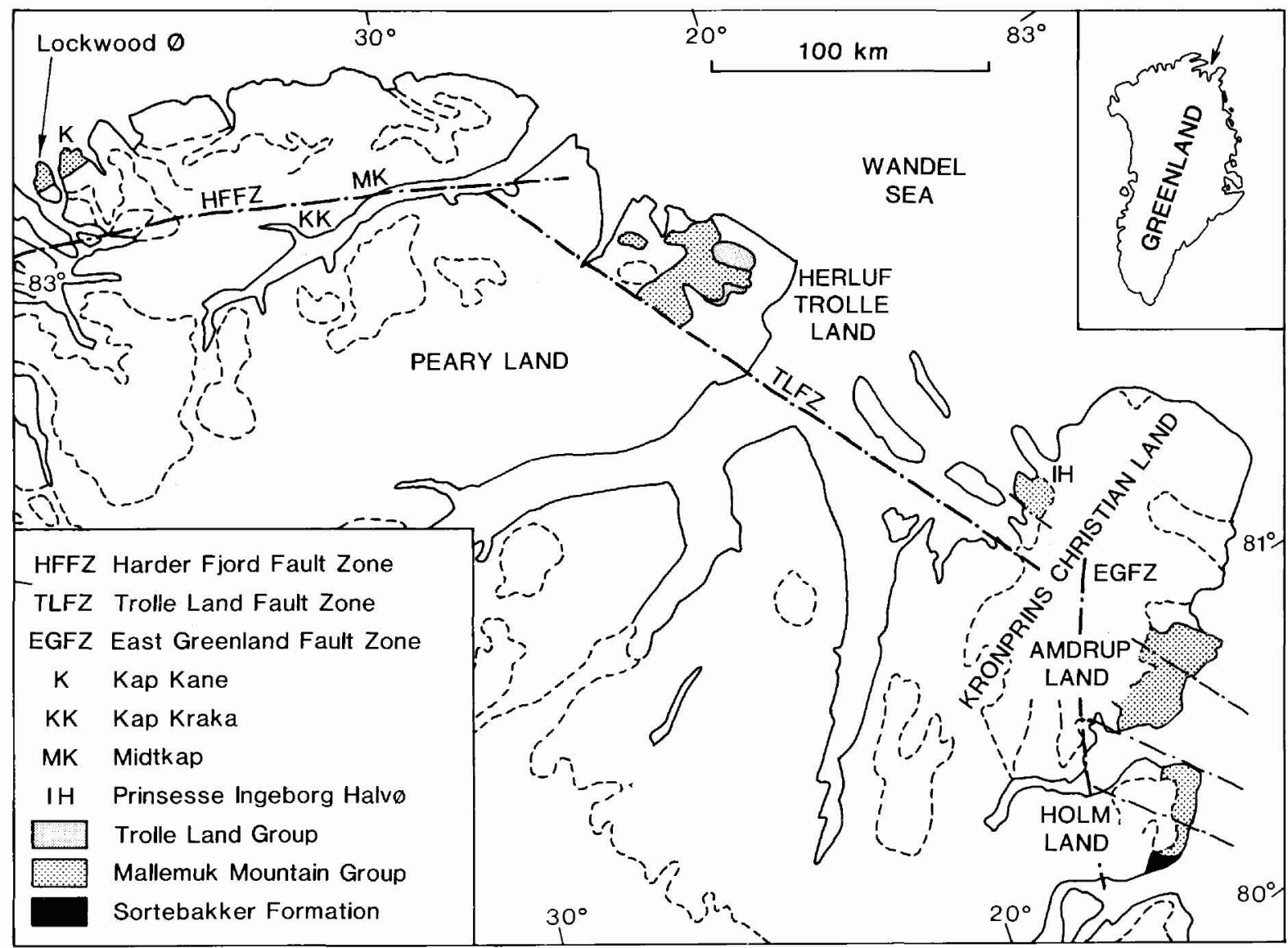

Fig. 1. Map of eastern and central North Greenland showing distribution of the major lithostratigraphic units and position of major fault zones.

\section{Previous work}

Upper Palaeozoic sediments were first discovered in eastern North Greenland by J. P. Koch and A. Wegener during the Danmarks Expedition in 1906-08 (Nathorst, 1911; Grönwall, 1916). On the basis of their material Nathorst (1911) assigned the lower part of the sequence to the Early Carboniferous. Later, Grönwall (1916) divided the sequence into a lower Terrestrial Group overlain by a Lower Marine Group and an Upper Marine Group both suggested to be of Carboniferous age.

Koch (1929) included the Terrestrial Group in his Mt. Pictet Formation and united the Lower and Upper Marine Groups into the new Mallemuk Mountain Formation, which also included Carboniferous sediments found in eastern Peary Land by Koch (1923, 1925, 1929).

Renewed investigations of the Upper Palaeozoic sequence on Holm Land and Amdrup Land (fig. 1) were initiated when E. Nielsen measured a series of profiles along the coast in 1938 (Nielsen, 1941). His collections were described by Frebold (1950), and later by Dunbar et al. (1962), Dunbar (1962), Ross \& Dunbar (1962), Ross \& Ross (1962), and Bendix-Almgreen (1975). Meanwhile, Troelsen (1950) had discovered Upper PaIaeozoic and Triassic sediments in eastern Peary Land in the early phase of the Danish Peary Land Expedition. The Triassic sediments yielded abundant ammonites described by Kummel (1953).

Recently, information on the Carboniferous to Triassic sequence in North Greenland has been greatly expanded as a result of the large scale geological mapping project carried out by the Geological Survey of Greenland in 1978-1980 (Håkansson \& Heinberg, 1977; Håkansson, 1979; Soper et al., 1980; Håkansson et al., 1981; Wagner et al., 1982; Håkansson \& Stemmerik, 1984).

\section{Biostratigraphy}

The precision in the biostratigraphic dating of the Upper Palaeozoic and Triassic sediments in eastern 


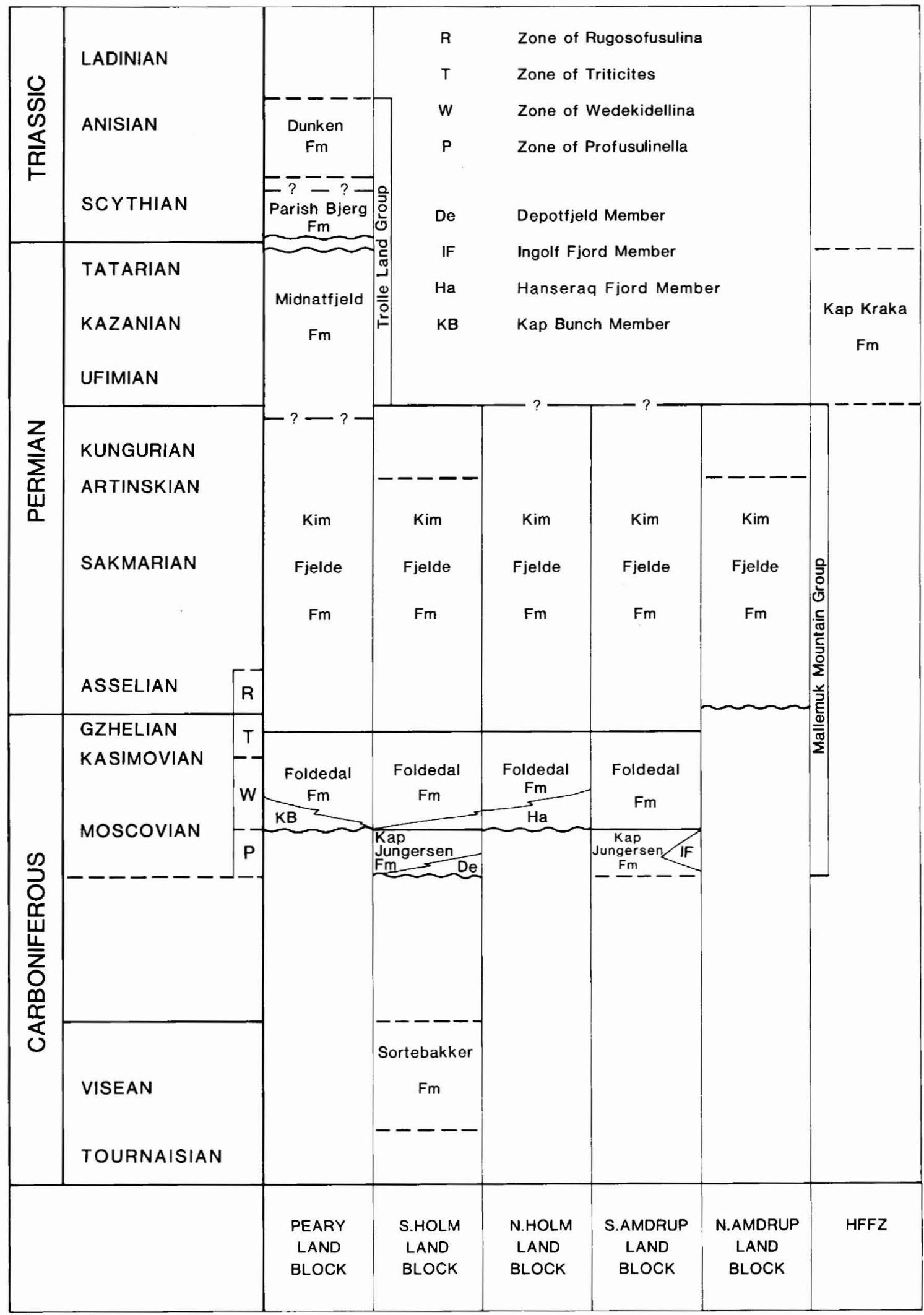

Fig. 2. Lithostratigraphic scheme for the Upper Palaeozoic and Triassic sediments in the Wandel Sea Basin. 
North Greenland is quite variable due to the many different groups of organisms involved. The present knowledge on the biostratigraphy, summarised below, is mainly due to work by Nathorst (1911), Dunbar et al. (1962), Ross \& Dunbar (1962), Kummel (1953), Petryk (1977), Balme (in Håkansson, 1979) and Wagner et al. (1982). Additional information was made available by Dawes (1976).

Sortebakker Formation. The Sortebakker Formation yields a macroflora that was described by Nathorst (1911). He assigned the flora to the Dinantian by comparison to the Dinantian flora of Spitsbergen. However, the flora has great similarities to the early Namurian flora of northern East Greenland described by Halle (1931, 1953) and Bütler (1961). Tentatively, we thus suggest a late Dinantian - early Namurian age for the formation, which then corresponds to the upper, widespread part of the Billefjorden Group in Spitsbergen (Steel \& Worsley, 1984).

Mallemuk Mountain Group. The main part of the Mallemuk Mountain Group is dated by means of fusulinids (Dunbar et al., 1962; Ross \& Dunbar, 1962; Petryk, 1977; J. E. Whittaker, personal communication). Dunbar et al. (1962) divided the Holm Land - Amdrup Land sequence into three fusulinid zones spanning the Carboniferous-Permian boundary. Later, Petryk (1977) documented the presence of yet another Late Carboniferous fusulinid zone in eastern Peary Land.

The zonation used here (fig. 2) corresponds largely to that used in Spitzbergen by Cutbill \& Challinor (1965). However, in accordance with common practice we treat the Rugosofusulina arctica zone as the basal Permian unit.

The youngest fusulinids so far found in North Greenland belong to the Rugosofusulina arctica zone (Dunbar et al., 1962; J. E. Whittaker, personal communication, 1985). More than $700 \mathrm{~m}$ of carbonates of proposed early Permian age occur above the highest presence of fusulinids (fig. 2). Dating of this sequence is somewhat speculative and mainly based on brachiopods, suggesting that the youngest part of the Mallemuk Mountain Group is of Kungurian age (Dunbar et al., 1962; Peel et al., 1974).

Trolle Land Group. The Midnatfjeld and Parish Bjerg Formations are only dated in very general terms (fig. 2).

Preliminary palynological studies suggest a late Early Permian age for the lower part of the Midnatfjeld Formation (Balme in Håkansson, 1979), while a Late Permian fauna referred to by Dawes (1976) most likely originates from the uppermost part of that formation

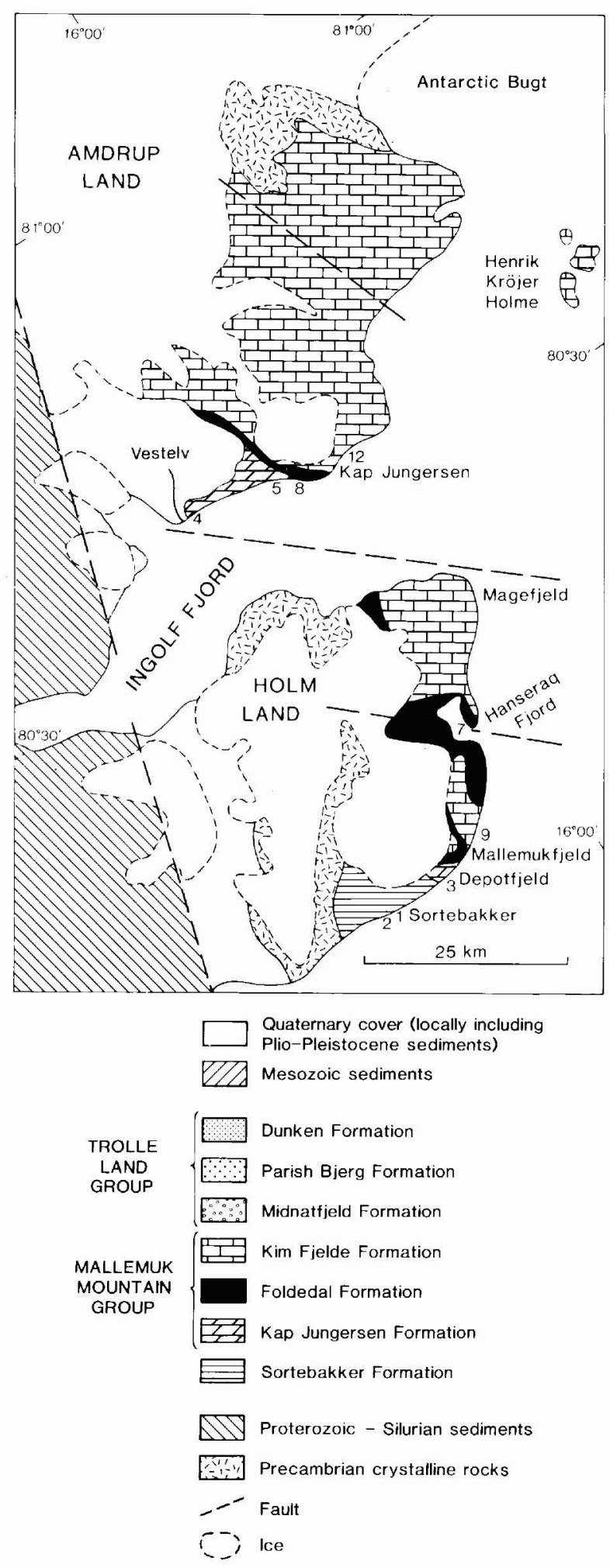

Fig. 3. Geological map of Holm Land and Amdrup Land showing distribution of the various Upper Palaeozoic formations, position of measured sections and locations mentioned in the text. Geology based on Henriksen (1981)-and own observations. Legend also refers to fig. 16. 


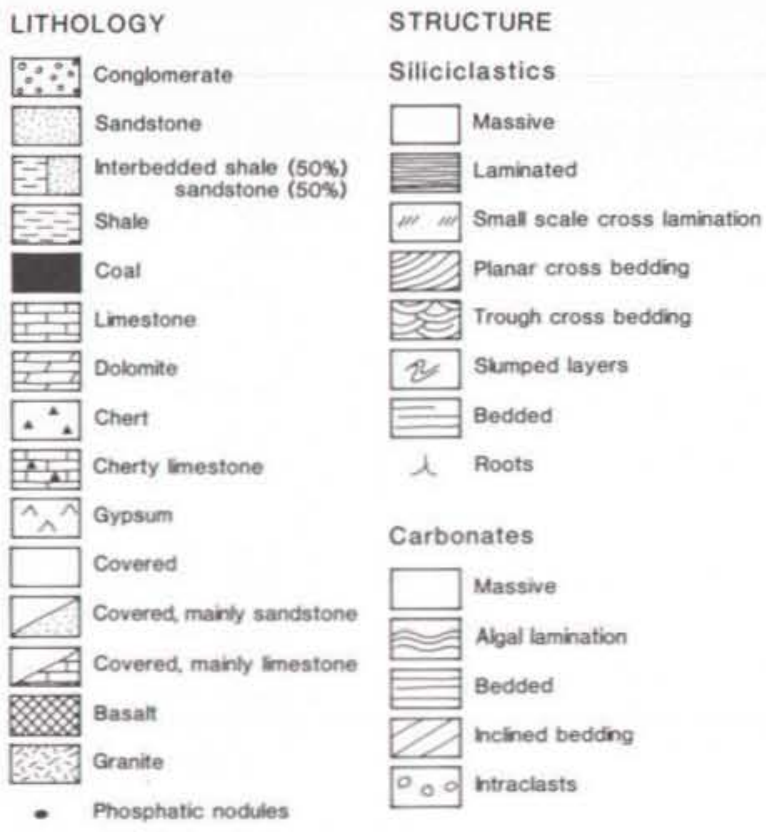

Fig. 4. Legend covering all figured sections.

(Hăkansson, 1979). The Parish Bjerg Formation is poorly dated. Palynological studies suggest a Triassic age for the formation (Balme in Håkansson, 1979). However, the presence of gastropods with a Palaeozoic aspect should also be mentioned.

The only well dated unit is the Dunken Formation which in the lower part yields a fauna of crinoids, brachiopods, pelecypods and fish indicating an Early Triassic (Scythian) age, while somewhat higher in the sequence an ammonite fauna of basal Middle Triassic (Anisian) age occurs (fig. 2) (Kummel, 1953).

Kap Kraka Formation. The Kap Kraka Formation was dated on the basis of macroflora remains as Late Permian by Wagner et al. (1982).

\section{Lithostratigraphy}

The depositional history of the Wandel Sea Basin in Carboniferous to Triassic time was related in various ways to the structural development of three major fault zones: the East Greenland Fault Zone (EGFZ), Trolle Land Fault Zone (TLFZ) and Harder Fjord Fault Zone (HFFZ) (fig. 1) (Hảkansson \& Stemmerik, 1984).

Deposition apparently took place in two different tectonic settings. The Lower Carboniferous - Lower Permian sediments in Holm Land and Amdrup Land were deposited in the northernmost part of the East Greenland rift basin which formed during the initial stages of rifting between Greenland and Norway, whereas the Upper Carboniferous - Triassic sediments in Peary Land were deposited along the southern margin of a rift basin that also included Svalbard.

Nevertheless, during Late Carboniferous - Early Permian times in particular, the sedimentary development was very uniform throughout eastern North Greenland and the entire arctic region. Accordingly, we have adopted the traditional view of the presence of a Wandel Sea Basin (Dawes \& Soper, 1973; Dawes, 1976; Hákansson \& Stemmerik, 1984) applying the same lithostratigraphy both in Peary Land and in the Holm Land - Amdrup Land area (fig. 2).

\section{Sortebakker Formation}

new formation

History. This formation corresponds to the continental Lower Carboniferous sediments of Nathorst (1911) and the Terrestrial Group of Grönwall (1916). Koch (1929) included the sediments in his Mt. Pictet Formation, but this name was later rejected by Håkansson et al. (1981).

Name. After Sortebakker situated along the south coast of Holm Land (fig. 3).

Type section. The type section (1) is located at Sortebakker (figs $3,5,7$ ).

Reference section. A reference section (2) has been measured at Sortebakker (figs 3, 5, 6).

Thickness. The thickness is inferred to exceed $600 \mathrm{~m}$.

Lithology. The formation is composed of cyclically interbedded medium to coarse grained sandstones, shale and minor coal (fig. 7). The formation includes more than 70 fining-upward cycles which may be traced laterally for several kilometres (fig. 6). The formation is divided by at least one internal low-angle unconformity into a lower, $350 \mathrm{~m}$ thick unit composed of thin, shale dominated cycles, and an upper sandy unit with thick cycles. Coal appears to be confined to the upper part of the formation above the unconformity.

Boundaries. The lower boundary is unknown. The formation is overlain with an angular unconformity by sediments of the Kap Jungersen Formation (fig. 6).

Distribution. The formation has a restricted occurrence along the south coast of Holm Land (fig. 3). 


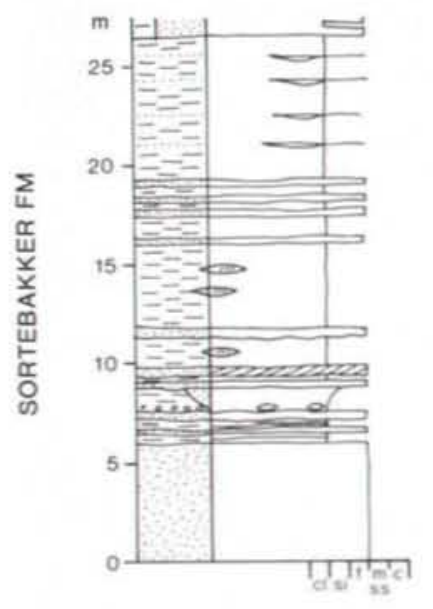

A

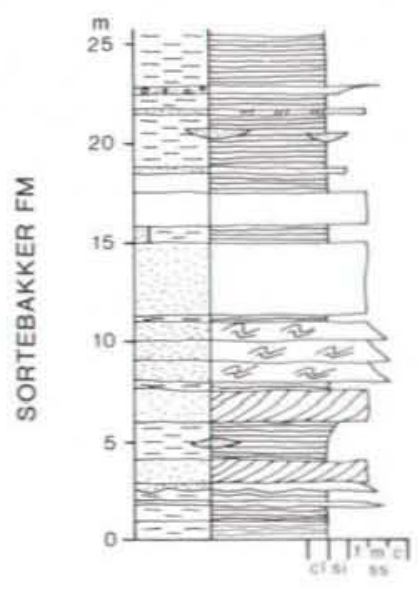

B

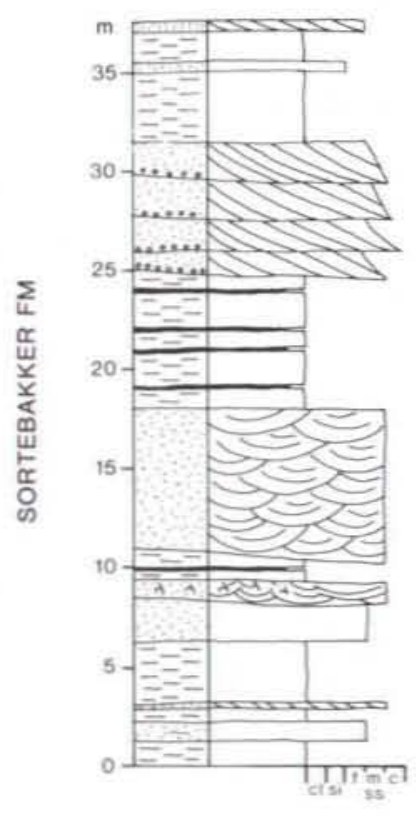

C

Fig. 5. Detailed sediment log of Sortebakker Formation. (A) Section 1, lower part (Type section). (B) Section 1 upper part. (C) Section 2. For location see figs 3 and 6.

Age. Early Carboniferous, (?) late Dinantian - early Namurian.

\section{Mallemuk Mountain Group}

History. This unit was originally defined as the Mallemuk Mountain Formation by Koch (1929). Later, Hảkansson (1979) raised its status to group level. The group comprises the Lower and Upper Marine Groups of Grönwall (1916).

Name. After the mountain Mallemukfjeld in Holm Land (figs 3,8).

Type area. The cliffs along the south and east coast of Holm Land (fig. 3).

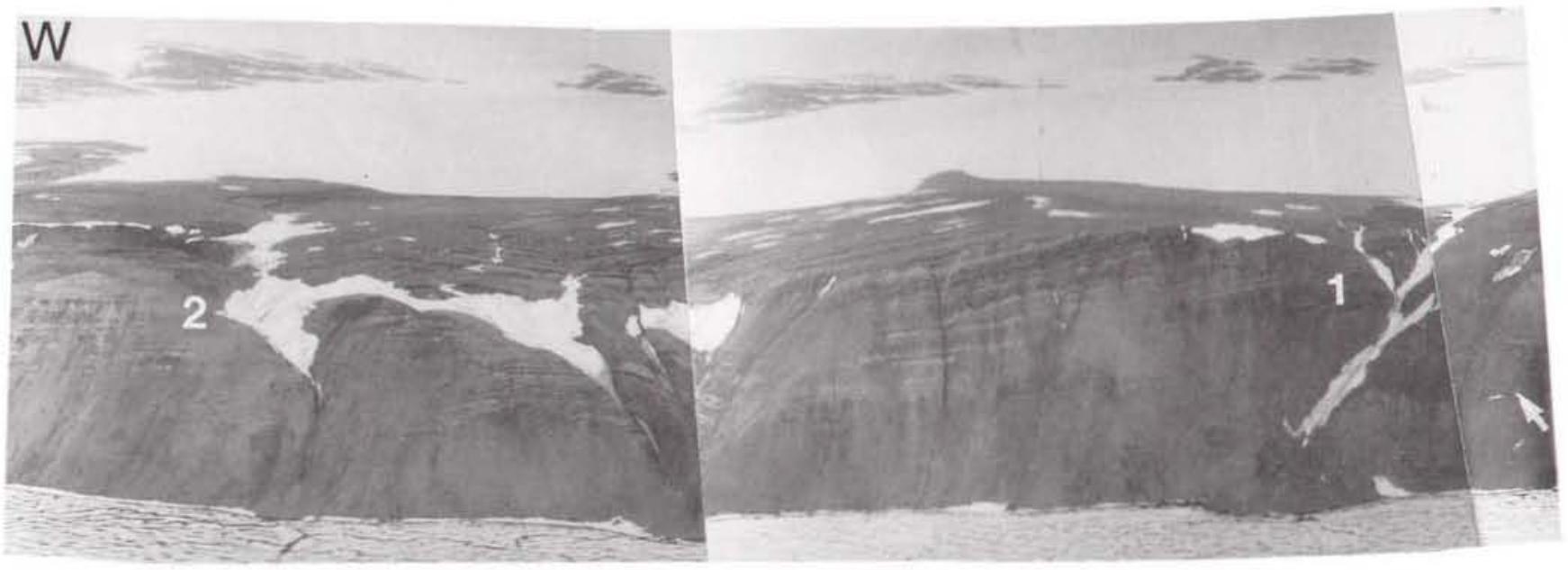

Fig. 6. The coastal cliffs of Sortebakker showing location of sections (1) and (2). Note the internal disconformities (arrows) within the Sortebakker Formation (S) and the unconformity to the overlying Kap Jungersen Formation (K). Cliff height approximately $350 \mathrm{~m}$. 
Thickness. More than $1100 \mathrm{~m}$.

Dominant lithology. The lower part of the group is dominated by interbedded sandstones, shales and shelf carbonates of the Kap Jungersen and Foldedal Formations. The upper part of the group consists of highly fossiliferous thin bedded to massive limestones of the Kim Fjelde Formation.

Boundaries. The group rests on the Sortebakker Formation in southern Holm Land with an angular unformity (fig. 6). Elsewhere in Holm Land and Amdrup Land it rests directly on Precambrian basement. In Peary Land and Prinsesse Ingeborg Halvø the group rests on a variety of Lower Palaeozoic rocks from the North Greenland fold belt.

The upper boundary is known from eastern Peary Land and the Lockwood $\emptyset$ area. Throughout most of this area, sediments of the Midnatsfjeld Formation conformably overlie the Mallemuk Mountain Group. However, locally the Upper Jurassic - Lower Cretaceous Ladegårdsåen Formation (Hákansson, 1979) rests with an angular unconformity on top of the group.

Distribution. The group occurs from Lockwood $\emptyset$ in the west to Holm Land in the south-east (fig. 1).

Geological age. Late Carboniferous (early Moscovian) to Early Permian (Kungurian) (fig. 2).

Subdivisions. Three formations, in ascending order, constitute the group; Kap Jungersen Formation $(+350$ $\mathrm{m})$, Foldedal Formation $(+400 \mathrm{~m})$, Kim Fjelde Formation $(700 \mathrm{~m})$.

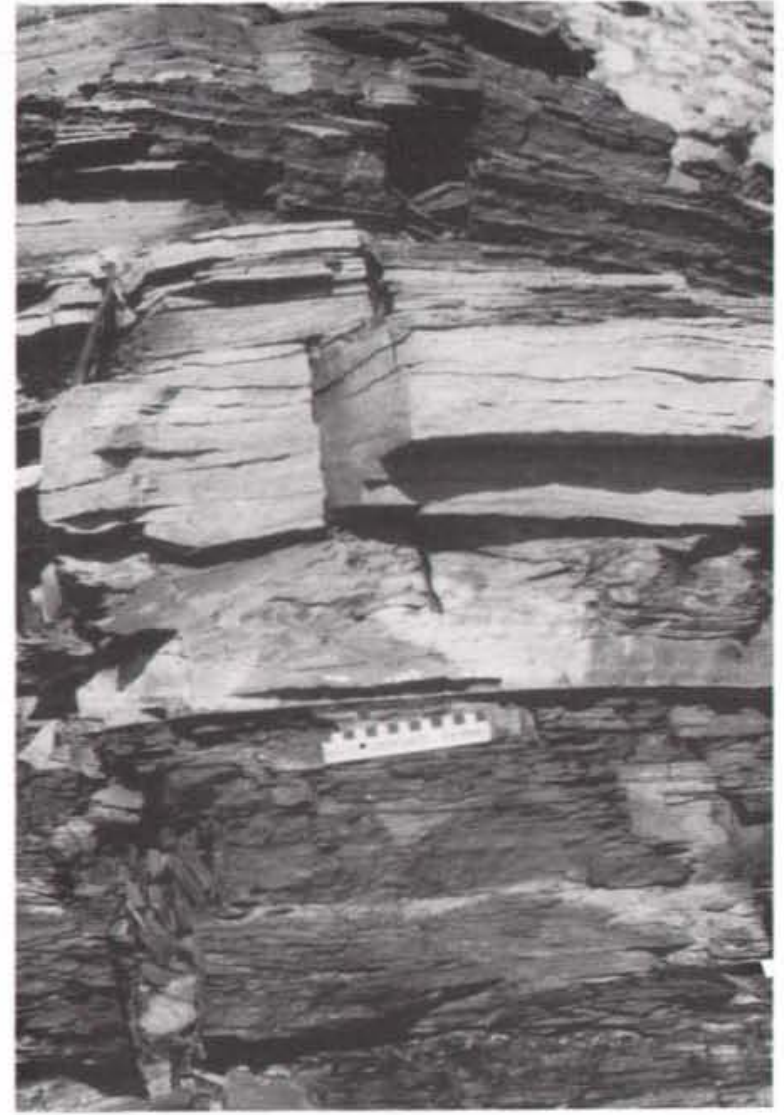

Fig. 7. Interbedded sandstone and shale interpreted to be fining upward cycles of flood plain origin. Sortebakker Formation, section 1.

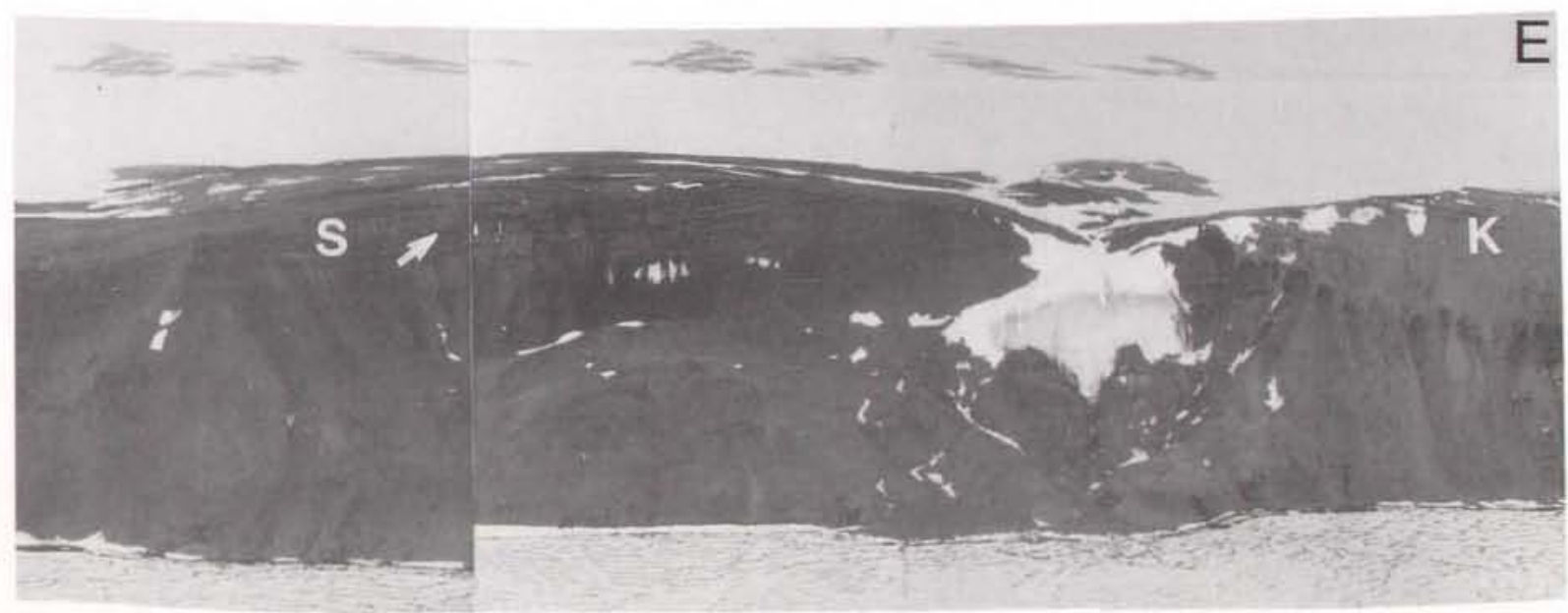




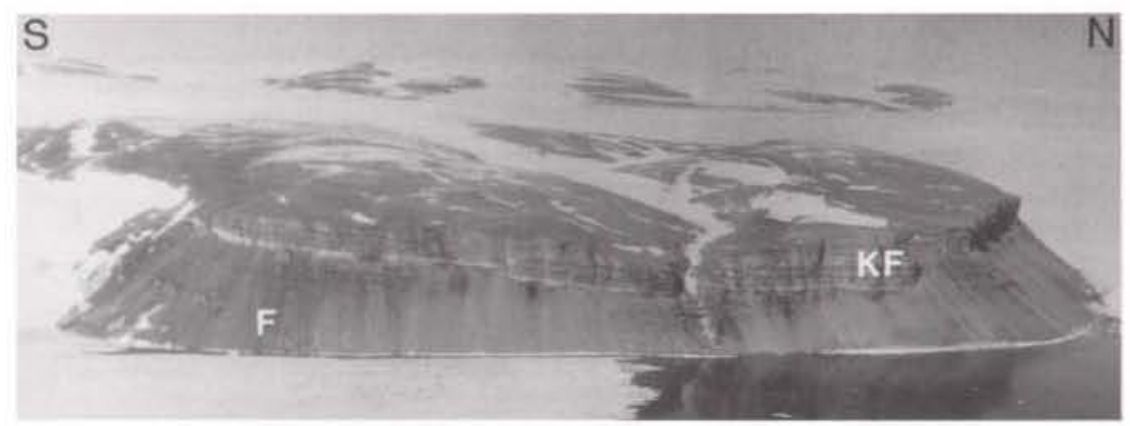

Fig. 8. Mallemukfjeld seen from the east. The thick cliff forming unit is the Kim Fjelde Formation (KF). The interbedded limestones and sandstones below belong to the Foldedal Formation (F). Cliff height approximately $400 \mathrm{~m}$.

\section{Kap Jungersen Formation}

new formation

History. This formation corresponds to the lower part of the Lower Marine Group of Grönwall (1916).

Name. After Kap Jungersen, south-eastern Amdrup Land (fig. 3).

Type section. The type section 4 is from Vestelv, southern Amdrup Land (figs 9, 10).

Reference sections. Reference sections occur at Depotelv (section 3) in southern Holm Land and Kap Jungersen (section 5 ) in southern Amdrup Land (figs 3, 9, 11).

Thickness. $350 \mathrm{~m}$ in southern Holm Land and more than $300 \mathrm{~m}$ in southern Amdrup Land.

Lithology. The formation includes highly variable lith- ologies, including conglomerates, sandstones, shales, limestones and gypsum.

The basal part of the formation is composed of conglomerates and sandstones referred to as the Depotfjeld Member.

In Holm Land the main part of the formation consists of interbedded marine sandstones and biogenic limestones (fig. 12). The sandstones are medium-grained arkoses with a sparse, poorly preserved marine fauna. The limestones are biogenic wackestones and packstones with a fauna dominated by brachiopods and bryozoans. Isolated chaetetids occur frequently, and from a single level Stemmerik (1989b) reported the development of small chaetetid reefs. The upper part of the formation in Holm Land consists of well bedded biogenic wackestones and packstones.

In Amdrup Land the lower part of the formation consists of interbedded sandstone, shale and biogenic limestone (fig. 9a) that grade up into a sequence of well-bedded biogenic wackestone and packstone.

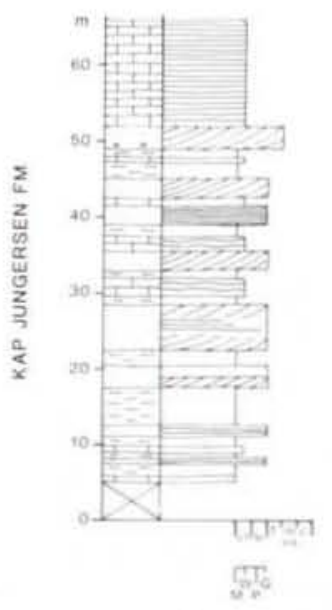

A

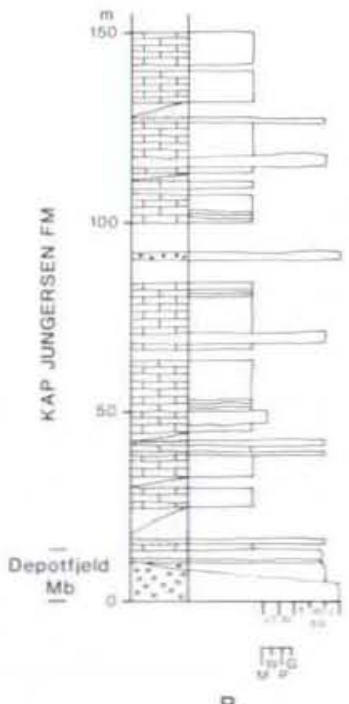

B

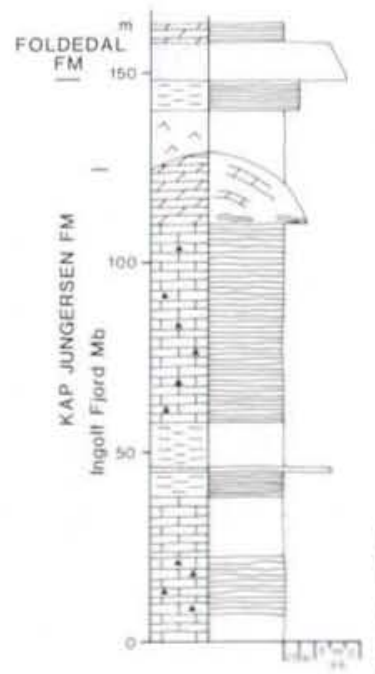

C
Fig. 9. Sediment $\log$ of the Kap Jungersen Formation. (A) Type section (4). (B) Reference section (3). (C) Reference section (5). For location see fig. 3 . 
Fig. 10. Vestelv seen from the south. The type section (4) is located east of the river. Height of section $80 \mathrm{~m}$.
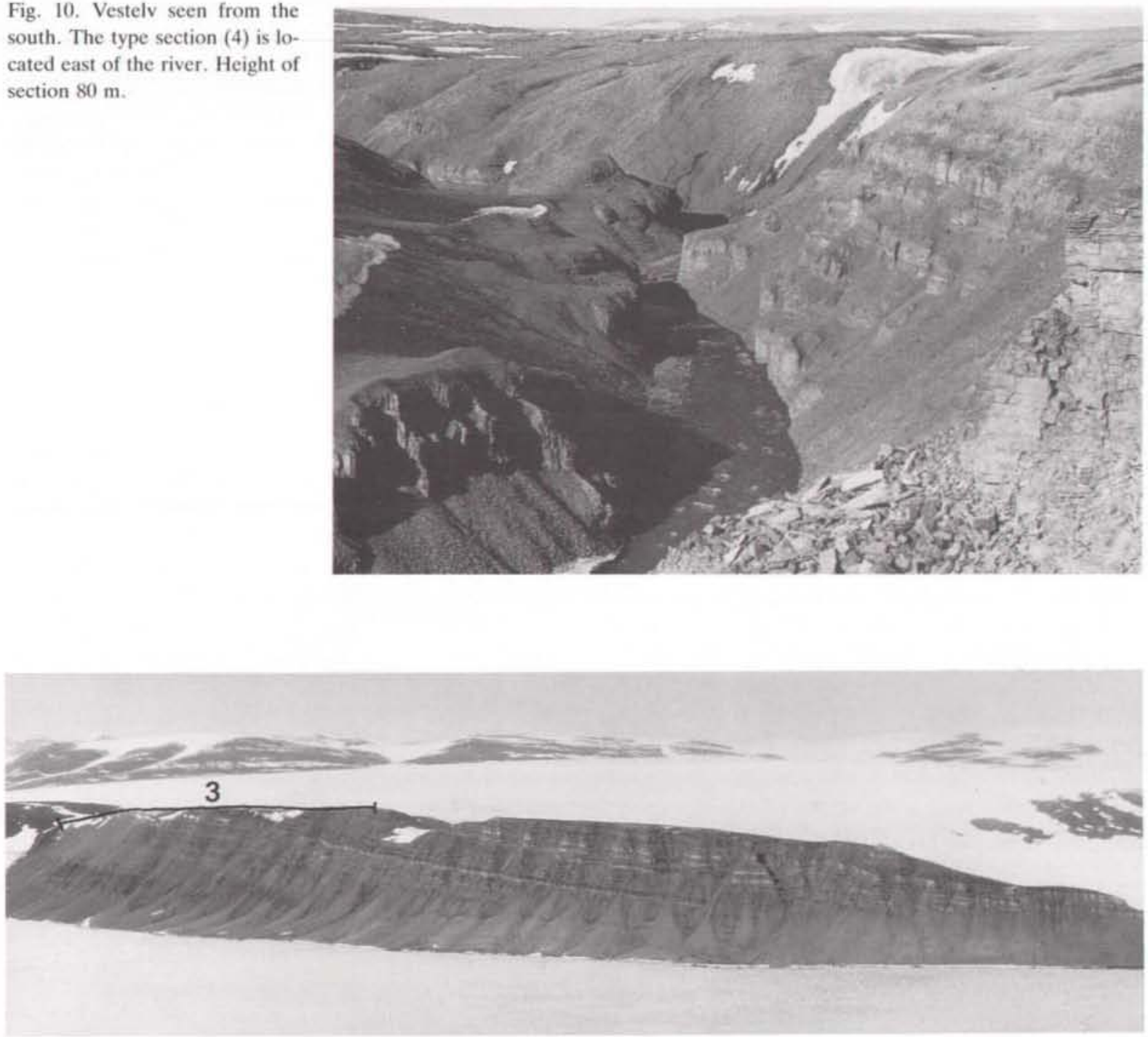

Fig. 11. Depotfjeld seen from the southeast. Location of section (3) is shown.

Fig. 12. Interbedded limestone and sandstone from the middle part of the Kap Jungersen Formation at Depotfjeld. Cliff height approximately $250 \mathrm{~m}$.

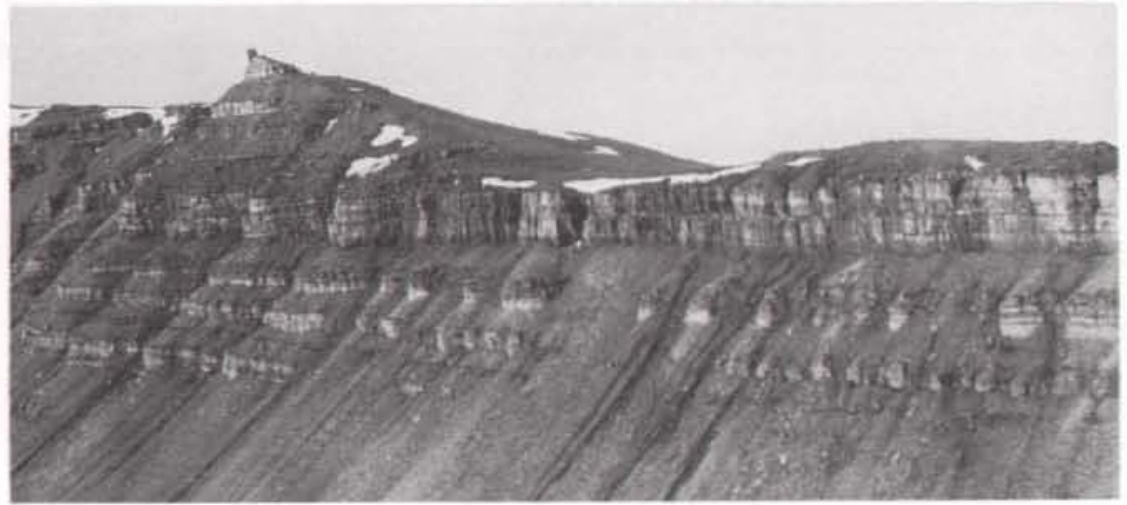




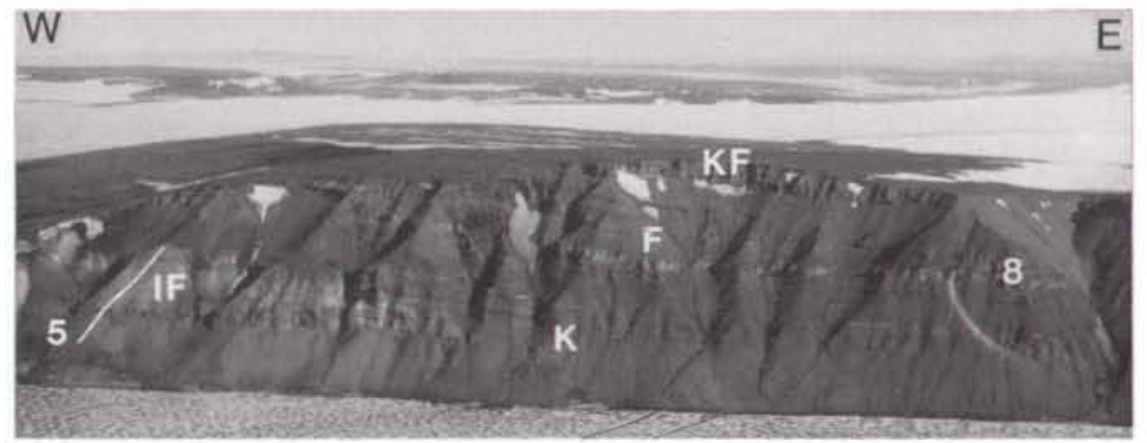

Fig. 13. The coastal cliffs between Vestelv and Kap Jungersen showing the Kap Jungersen Formation (K), Ingolf Fjord Member (IF), Foldedal Formation $(\mathrm{F})$ and Kim Fjelde Formation (KF). Location of sections 5 and 8 is shown. Cliff height approximately $350 \mathrm{~m}$.

The upper part of the formation is dominated by black shales with thin layers of gypsum. However, an approximately $2 \mathrm{~km}$ wide carbonate platform developed locally in the western part of Kap Jungersen (fig. 13). The hypersaline limestones and patch reefs creating this platform are separated out as the Ingolf Fjord Member.

Boundaries. The lower boundary is only exposed in southern Holm Land, where the formation rests unconformably on the Sortebakker Formation (fig. 14).

The formation is conformably overlain by the Foldedal Formation. The top of the formation in south-eastern Holm Land is defined as the top of a grey limestone unit immediately beneath a thick coarse-grained to conglomeratic sandstone unit. In the reference section at Kap Jungersen (fig. 9c) the top of a black shale beneath a thick sandstone unit forms the top of the formation.

Distribution. The formation occurs in the coastal cliffs from Depotfjeld to Hanseraq Fjord in Holm Land and along the south coast of Amdrup Land (fig. 3).
Age. Carboniferous, Early Moscovian, Profusulinella Zone (fig. 2).

Subdivisions. The Depotfjeld and Ingolf Fjord Members are separated out from the rest of the formation.

\section{Depotfjeld Member}

new member

Name. After Depotfjeld, southern Holm Land (fig. 3).

Type section. The type section is located at the western end of Depotfjeld (fig. 14) and corresponds to the lower part of the reference section (3) (fig. 9b).

Thickness. 0-40 m.

Lithology. The member consists of red-weathering conglomerates and coarse-grained sandstones. The con-

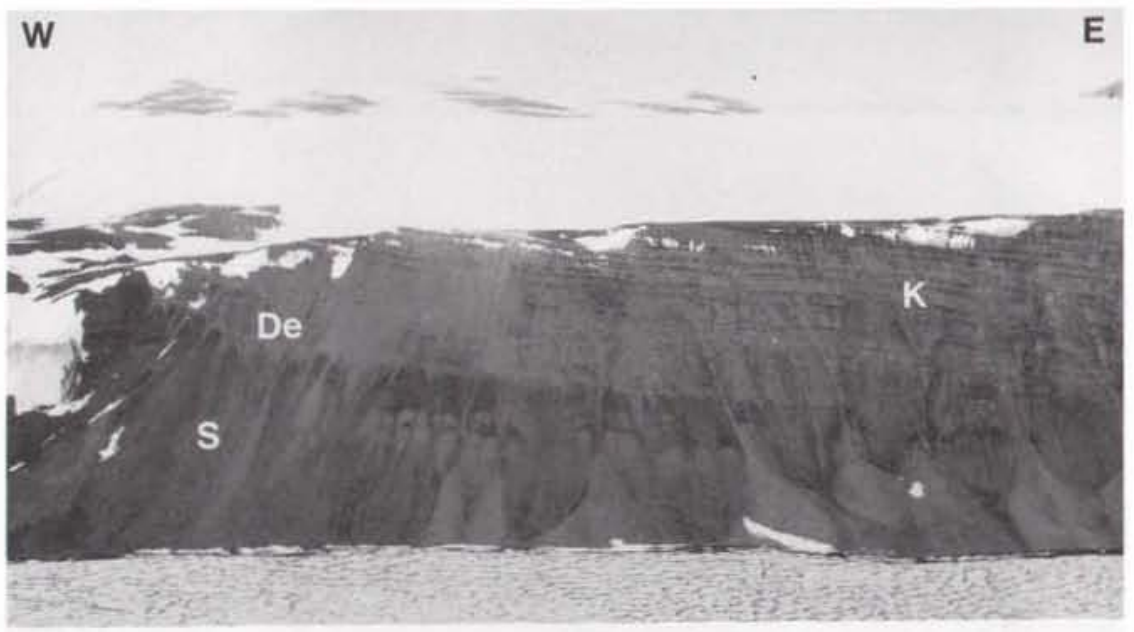

Fig. 14. Coastal cliffs of Depotfjeld showing details of the unconformity separating the Kap Jungersen Formation $(K)$ from the Sortebakker Formation (S). Depotfjeld Member (De) thins and disappears towards the east. Cliff height approximately $300 \mathrm{~m}$. 
Fig. 15, Hypersaline platform carbonates overlain by crinoidbryozoan mounds $(\mathrm{M})$ and gypsum (G). Western Kap Jungersen. The mound is $20 \mathrm{~m}$ high.

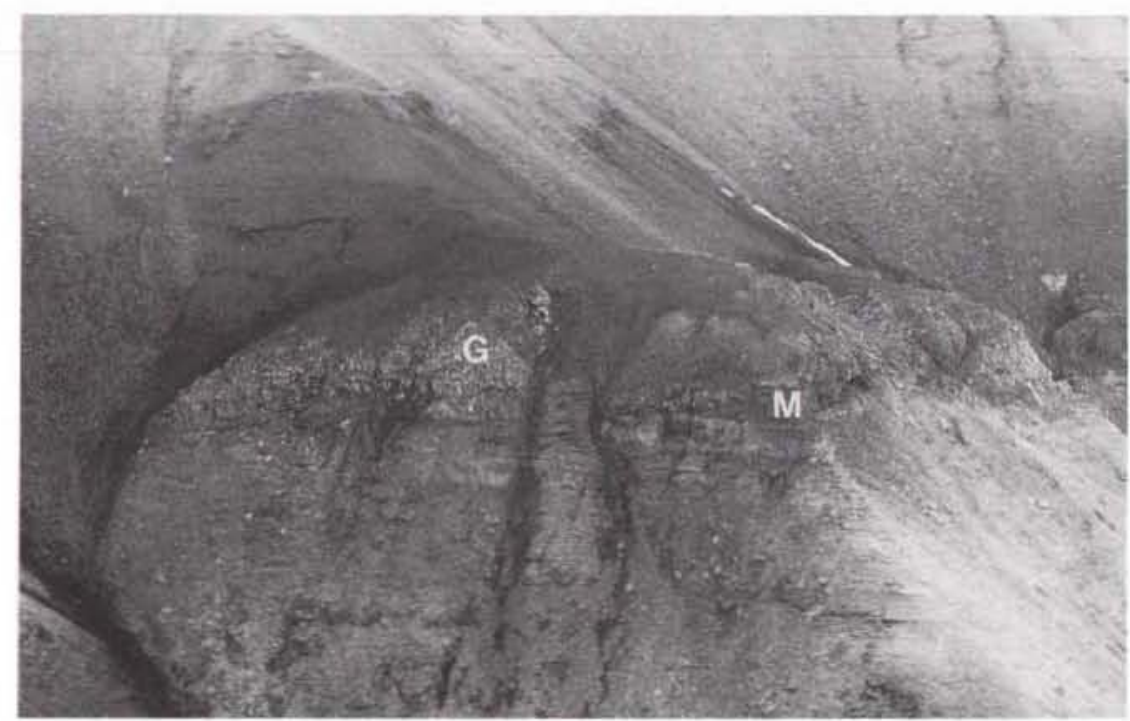

glomerates are composed of material derived from the crystaline basement exposed towards the west and north. Grain-sizes range from boulders at the base to gravel higher up. Internal structures are rare and only recognised in the upper, more fine-grained part, where large scale cross-bedding occurs.

Rare brachiopods and corals indicate deposition in a marine environment.

Boundaries. The lower boundary corresponds to the lower boundary of the formation. The upper boundary is placed at the first occurrence of limestone (fig. 9b).

Distribution. The member is restricted to the western part of Depotfjeld (fig. 11).

\section{Ingolf Fjord Member}

new member

Name. After Ingolf Fjord, the fjord between Holm Land and Amdrup Land (fig. 3).

Type section. The type section is located in the western part of the coastal cliffs at Kap Jungersen and corresponds to the basal part of section 5 (figs 9c, 13).

Thickness. $0 \mathrm{~m}$ to more than $150 \mathrm{~m}$.

Lithology. The main part of this member is composed of bedded, unfossiliferous limestone with subordinate amounts of shale (fig. 15). This part of the member forms a laterally restricted, hypersaline carbonate plat- form (fig. 13). On top of this, small 5-20 m high crinoidbryozoan mounds (fig. 15) formed in shallow water, normal marine environments (Stemmerik, 1989a). These mounds consist of dolomitized limestone with an abundant fauna of crinoids, bryozoans, brachiopods, bivalves and nautiloids.

Boundaries. The lower boundary is not exposed, but is tentatively placed at the base of the non-fossiliferous limestones. The upper boundary is irregular and placed at the transition from limestone to gypsum or shale (figs $9 c, 13)$. Laterally, this member also passes into black shales interbedded with gypsum.

Distribution. This member is restricted to the western part of Kap Jungersen.

\section{Foldedal Formation}

History. This name was introduced by Håkansson (1979) for a sequence of conglomerates and interbedded sandstones and limestones which forms the base of the Wandel Sea Basin sequence around Foldedal and Clarence Wyckoff Bjerg in eastern Peary Land (fig. 16). Subsequent work has led to the inclusion of comparable sequences in Holm Land, Amdrup Land and the Lockwood $\emptyset$ area. The formation corresponds to the upper part of the Lower Marine Group of Grönwall (1916) in Holm Land and Amdrup Land.

Name. After Foldedal, eastern Peary Land (fig. 16).

Type section. The type section (6) is situated on the north side of Foldedal (figs 16, 17). 
Reference section. Reference sections occur at Hanseraq Fjord, Kap Jungersen, Mallemukfjeld and Lockwood $\emptyset$ (sections 7, 8, 9, 10, figs $1,3,16,17$ ).

Thickness. Highly variable due to variations in the underlying basement relief. In the type section the measured thickness is $208 \mathrm{~m}$, but Hăkansson (1979) estimates a maximum thickness in excess of $400 \mathrm{~m}$ for the Foldedal area. In the Holm Land - Amdrup Land area the formation is $170-180 \mathrm{~m}$ thick.

Lithology. The lower part of the formation consists of red-weathering conglomerates and sandstones, here referred to as the Hanseraq Fjord and Kap Bunch Members. Above follows a sequence of interbedded marine sandstone and biogenic limestones which upwards becomes dominated by limestones (fig. 18). Locally, in southern Amdrup Land thin layers of gypsum and more fine-grained clastics occur.

Boundaries. In eastern Peary Land the formation rests unconformably on a variety of rocks from the North Greenland fold belt (Hảkansson, 1979). At Hanseraq Fjord it rests unconformably on Precambrian basement (figs 17b, 19), whereas elsewhere in Holm Land and Amdrup Land it overlies the Kap Jungersen Formation conformably. Here, the base of the formation is placed at the base of a thick conglomeratic sandstone overlying a thick sequence of limestone or locally black shale (figs $9 c, 13)$.

The upper boundary is placed above the uppermost sandstone which is followed by the cliff forming limestones of the Kim Fjelde Formation.

Distribution. The formation occurs in Peary Land south of Clarence Wyckoff Bjerg from Hellefiskefjord to Foldedal and along the north-western slopes of Kim Fjelde (fig. 16). In Holm Land it occurs in the coastal cliffs from Mallemukfjeld to Măgefjeld (fig. 3). In Amdrup Land it is restricted to the south-eastern part of the Kap Jungersen area (fig. 3). The formation also occurs in the Lockwood $\emptyset$ area.

Age. Carboniferous, Late Moscovian - early Gzhelian, Wedekindellina - and Tricites Zones (fig. 2).

Subdivisions. The Hanseraq Fjord and Kap Bunch Members are separated out from the rest of the formation. They are of similar lithology and age, but the wide geographical separation and their relation to local tectonic movements argue for a division into two members.

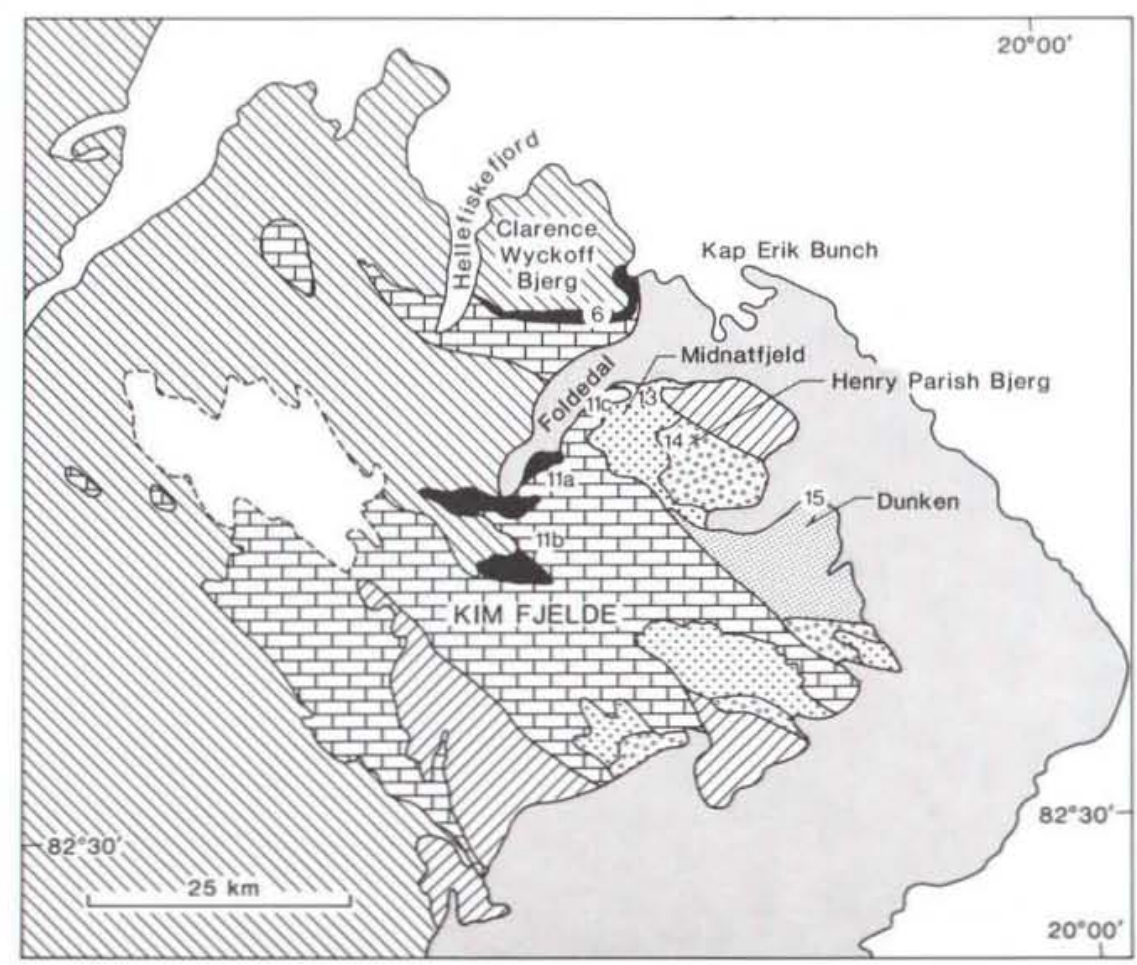

Fig. 16. Geological map of eastern Peary Land showing distribution of the various Upper Palaeozoic and Triassic Formations and position of measured sections. For legend see fig. 3. Geology modified from Bengaard \& Henriksen (1986). 


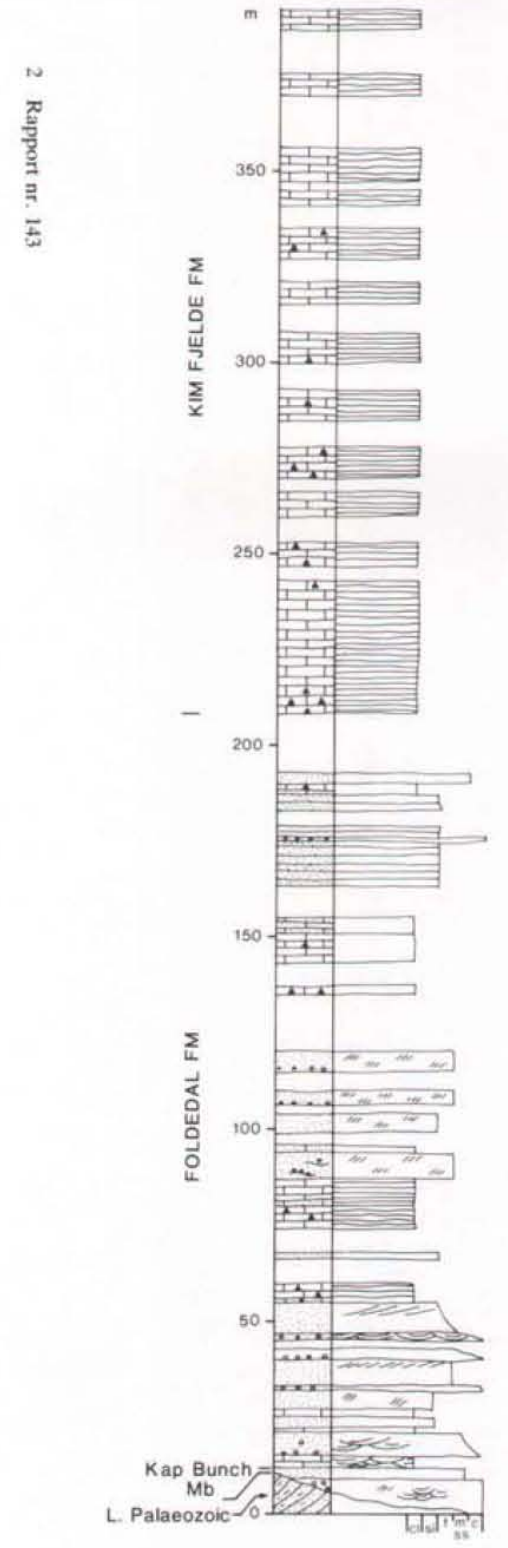

एका
Fig. 17. Sediment logs of the Foldedal Formation. (A) The type section (6), log measured by J. R. Ineson and R. L. Christie in 1978. (B) Reference section (7). (C) Reference section (8). (D) Reference section (9). (E) Reference section (10). For location see figs 3 and 16.

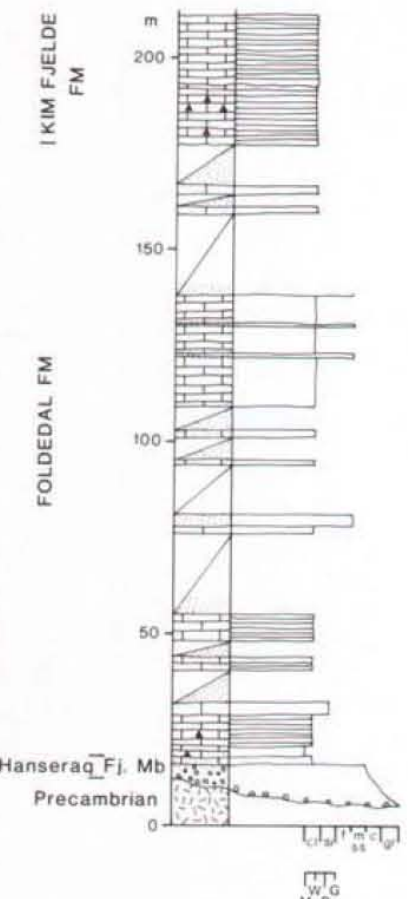

B

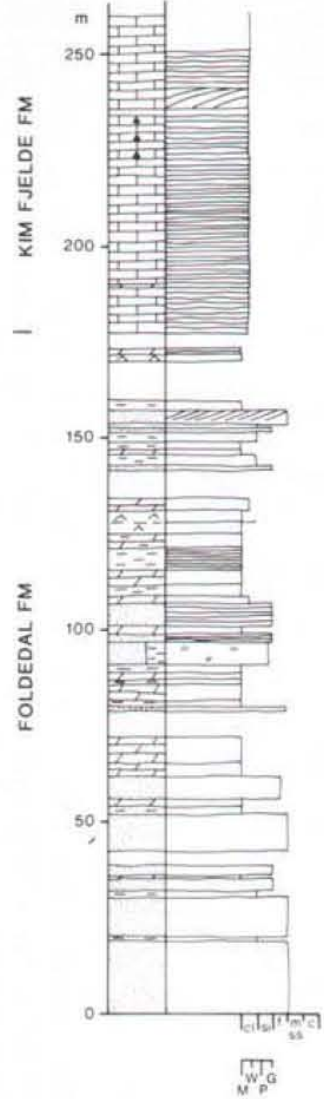

C

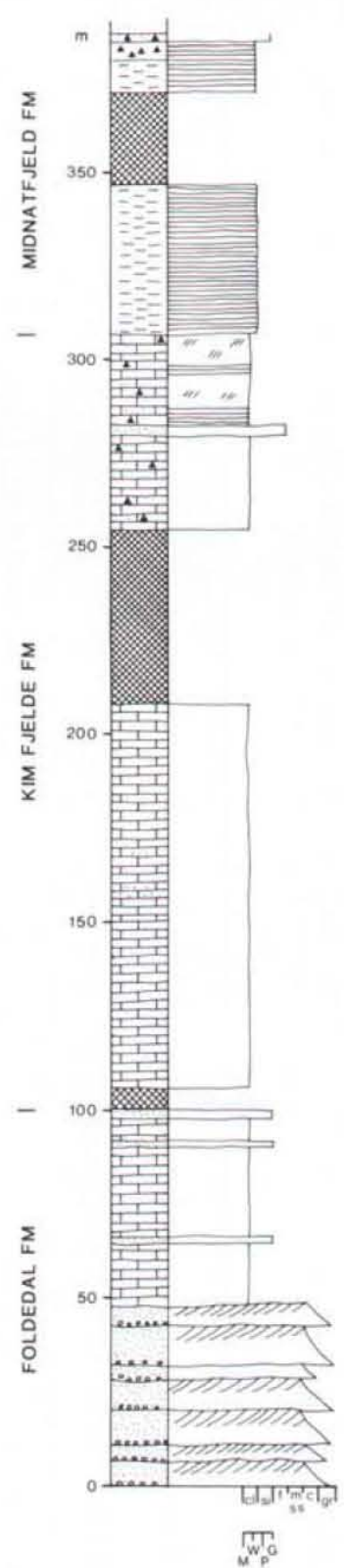

D

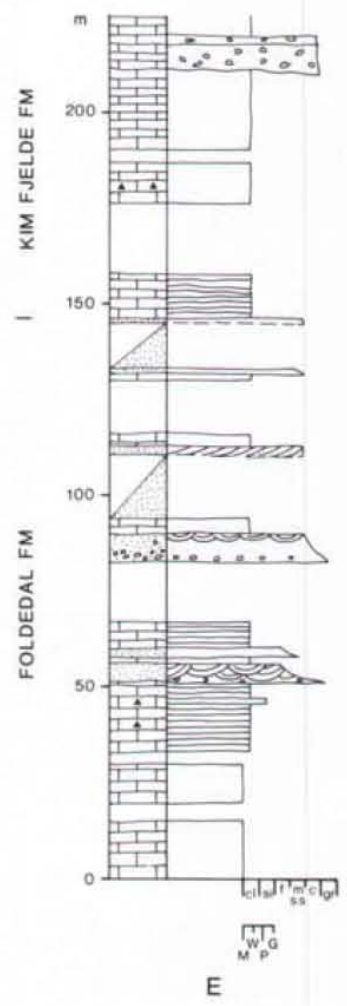




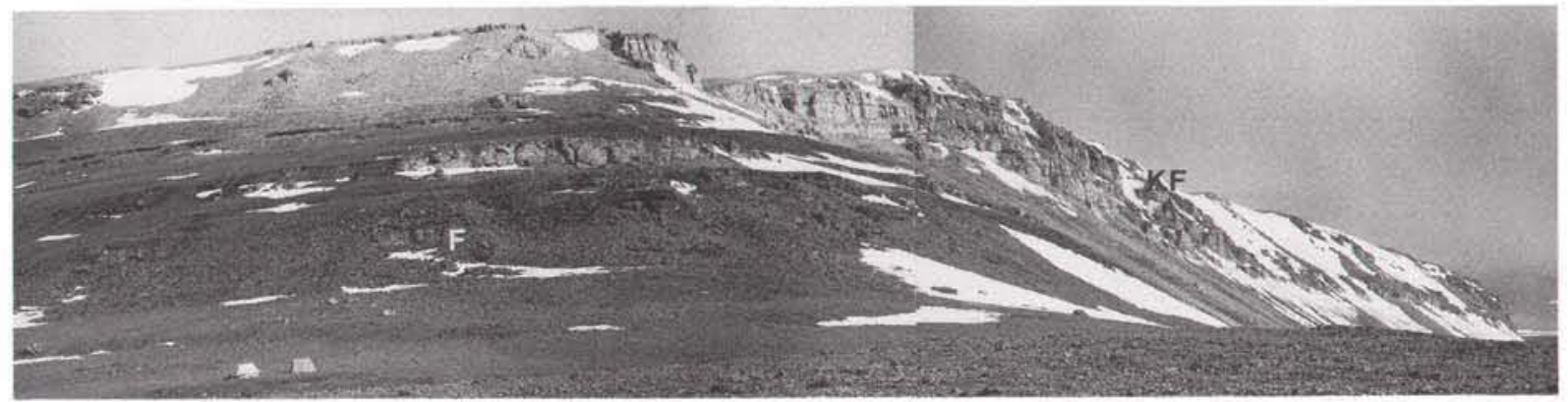

Fig. 18. The coastal cliffs on the north side of Hanseraq Fjord showing interbedded sandstone and limestone of the Foldedal Formation ( $\mathrm{F}$ ) overlain by cliff forming limestones of the Kim Fjelde Formation (KF). Tents for scale.

\section{Hanseraq Fjord Member}

new member

Name. After Hanseraq Fjord in Holm Land (fig. 3).

Type section. The type section corresponds to the lower part of the reference section (7) for the formation (fig. 17b).

Thickness. Highly variable, due to the relief of the underlying basement, estimated to be in the range $0-40$ $\mathrm{m}$.

Lithology. Red weathering conglomerates and coarsegrained sandstones, composed of material derived from the Precambrian basement towards the west. Sparse brachiopods indicate deposition in a marine environment.

Boundaries. The lower boundary corresponds to the lower boundary of the formation. The upper boundary is placed at the base of the first limestone bed.

Distribution. This member is exposed in the coastal cliffs north-east of Hanseraq Fjord, towards the south to Mallemukfjeld.

Age. Carboniferous, Late Moscovian, Wendekindellina Zone (fig. 2).

\section{Kap Bunch Member}

new member

Name. After Kap Erik Bunch in eastern Peary Land.
Type section. The type section corresponds to that of the Foldedal Formation (fig. 17a).

Thickness. Highly variable due to the relief of the underlying basement, estimated to be $0-200 \mathrm{~m}$.

Lithology. Red weathering conglomerates and crossbedded sandstones composed of material derived from the underlying basement. A sparse fauna dominanted by corals indicates marine conditions during deposition.

Boundaries. The lower boundary corresponds to that of the formation. The upper boundary is placed at the base of the lowermost limestone bed (fig. 17a).

Distribution. This member is confined to eastern Peary Land and Lockwood $\emptyset$.

Age. Carboniferous, Late Moscovian, Wedekindellina Zone (fig. 2).

\section{Kim Fjelde Formation}

History. This name was given by Håkansson (1979) to a thick series of limestones of Late Carboniferous to Early Permian age found in eastern Peary Land. The formation corresponds to the Upper Marine Group of Grönwall (1916) in Holm Land and Amdrup Land.

Name. After the mountainous area Kim Fjelde in eastern Peary Land (fig. 16).

Type section. The type section is in Foldedal (figs 16, 20). No single section can be measured through the entire formation, so the section 11c in fig. 20a spanning the upper Kim Fjelde Formation to the lower Midnatfjeld Formation is designated as type section. 
Fig. 19. Precambrian basement overlain by conglomerates and sandstone of the Hanseraq Fjord Member, Hanseraq Fjord.
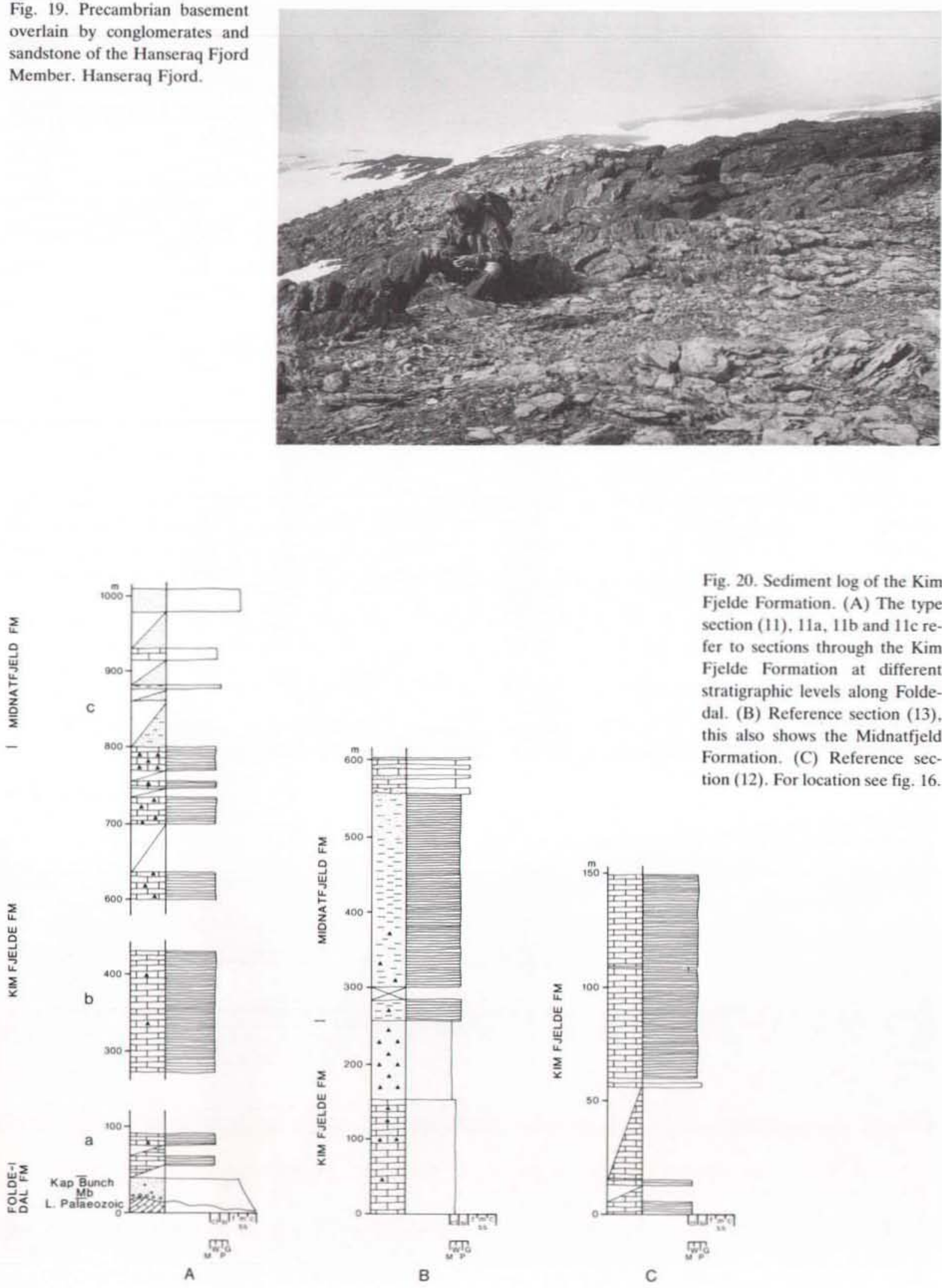

Fig. 20. Sediment log of the Kim Fjelde Formation. (A) The type section (11), 11a, $11 \mathrm{~b}$ and $11 \mathrm{c}$ refer to sections through the Kim Fjelde Formation at different stratigraphic levels along Foldedal. (B) Reference section (13), this also shows the Midnatfjeld Formation. (C) Reference section (12). For location see fig. 16.

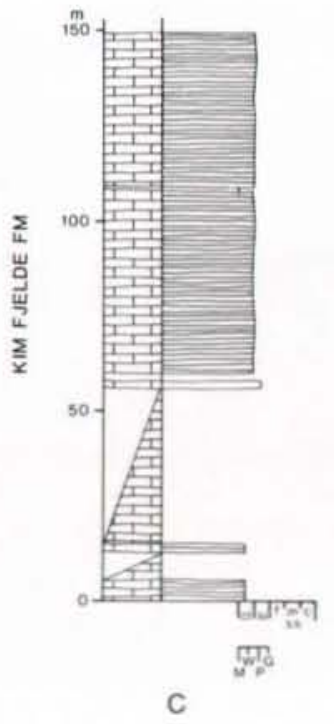


Reference sections. Reference sections covering the lower part of the formation occur in eastern Peary Land (section 6), Hanseraq Fjord (section 7), Kap Jungersen (section 8), Mallemukfjeld (section 9) and Lockwood Ø (section 10) (fig. 17). Reference sections through the upper part of the formation are measured at Kap Jungersen (section 12) and Midnatfjeld (section 13) (figs 3, 16,20 ).

Thickness. In Holm Land the formation is at present not known to be more than $150 \mathrm{~m}$ thick. In Amdrup Land the thickness varies from more than $550 \mathrm{~m}$ at Kap Jungersen to approximately $400 \mathrm{~m}$ near Antarctic Bugt. In Prinsesse Ingeborg Halvø the thickness is less than $200 \mathrm{~m}$. In eastern Peary Land, the only place where the entire formation is preserved the thickness is estimated to be $700 \mathrm{~m}$ (Håkansson, 1979).

Lithology. The formation is composed almost exclusively of fossiliferous or cherty limestones (fig. 21). In most places the limestones comprise well bedded wackestones and packstones of fragmented skeletal grains
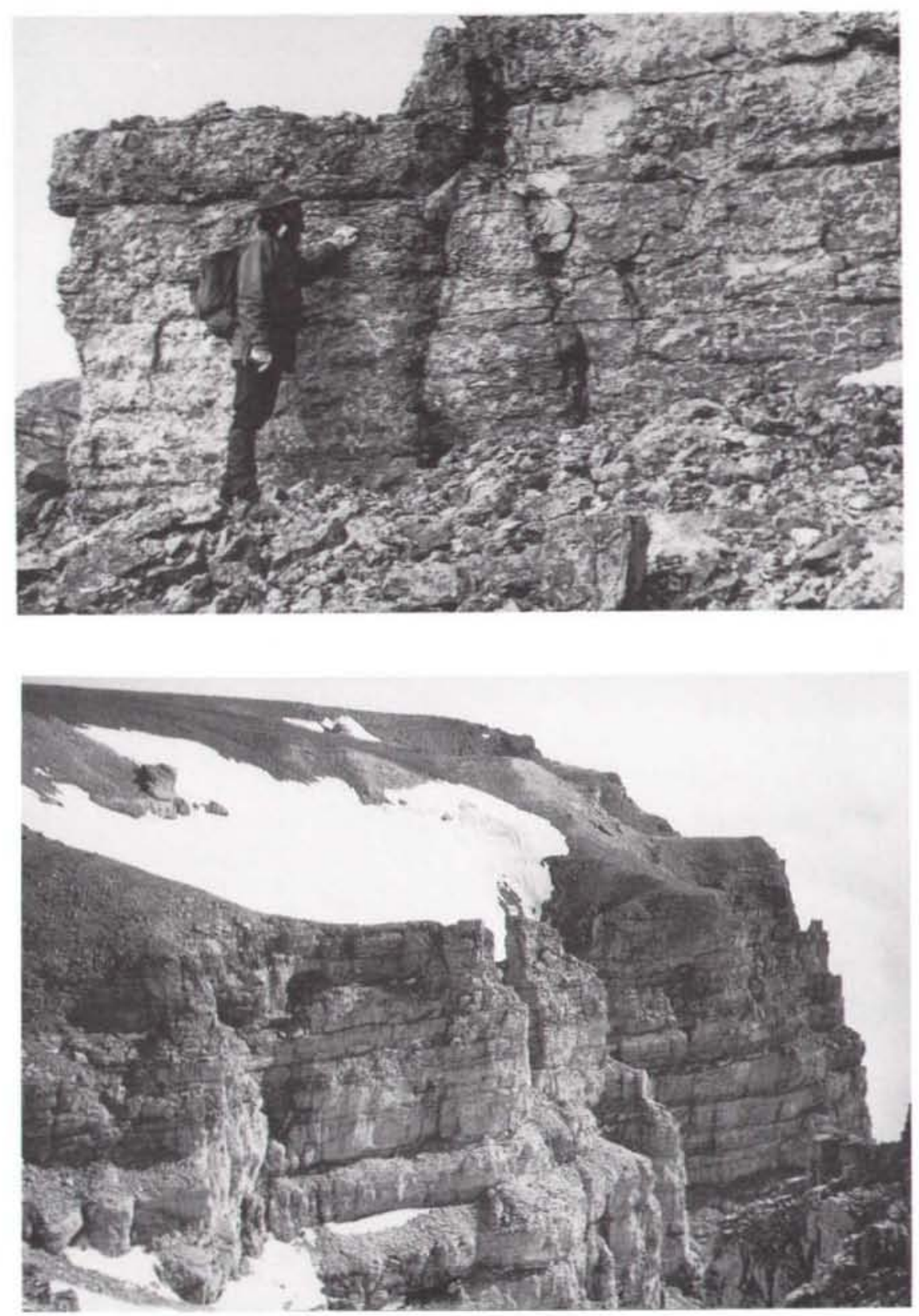

Fig. 21. Cherty limestone in the upper part of the Kim Fjelde Formation at Kim Fjelde.
Fig. 22, Bedded biogenic limestones in the upper part of the Kim Fjelde Formation at Kap Jungersen (section 12). Cliff height approximately $50 \mathrm{~m}$. 


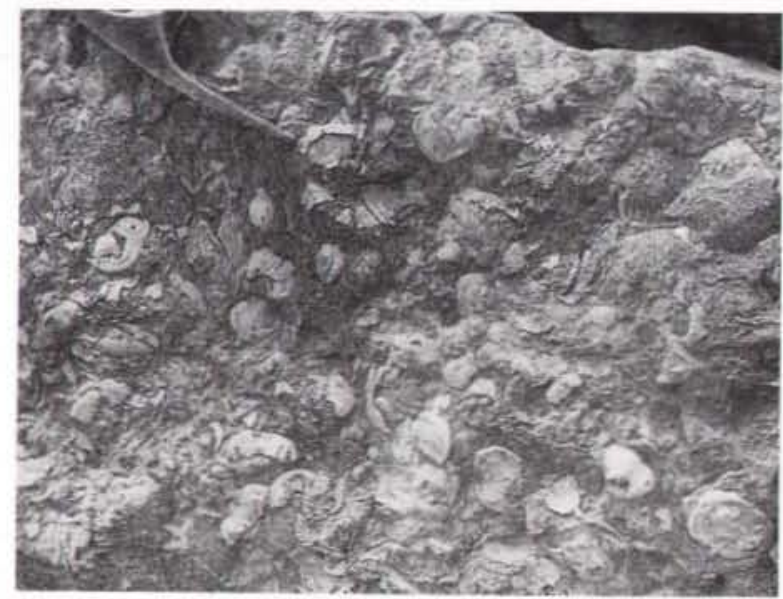

Fig. 23. Bedding plane showing abundance of chertified brachiopods. Kim Fjelde Formation at Kap Jungersen (section 12).

(fig. 22). Locally, in the upper part there are in situ accumulations of often silicified brachiopods and bryozoans (fig. 23). In Amdrup Land thin interbeds of red siltstones occur in the central part of the formation (fig. 24).

Boundaries. In northern Holm Land, southern Amdrup Land, eastern Peary Land and on Lockwood $\varnothing$ the formation conformably overlies sediments belonging to the Foldedal Formation (fig. 17). Here, the boundary is placed above the uppermost sandstone bed. In northern Amdrup Land, Prinsesse Ingeborg Halvø and locally in eastern Peary Land, the formation rests unconformably on, respectively, Precambrian basement and folded sediments of the Franklinian basin (Hảkansson, 1979; Hãkansson et al., 1981).

The upper boundary is recognised only in eastern Peary Land and in the Lockwood $\emptyset$ area. Here, the formation in most places is overlain conformably by clastic sediments of the Midnatfjeld Formation (fig. 20). The boundary is sharp and placed at the transition to dominantly siliciclastic lithologies. Locally, in eastern Peary Land the formation is unconformably overlain by the Upper Jurassic - Lower Cretaceous Ladegårdsàen Formation (fig. 16) (Håkansson, 1979).

Distribution. The formation is the most widespread of the Upper Palaeozoic units occurring in Holm Land, Amdrup Land, on northern Prinsesse Ingeborg Halvø, in eastern Peary Land and as far west as Lockwood $\emptyset$ and Kap Kane (figs 1, 3, 16).

Age. Late Carboniferous to Early Permian (?Kungurian). The lower boundary appears diachronous across the Carboniferous-Permian boundary being oldest in eastern Peary Land (Tricites Zone) and youngest in northern Amdrup Land and Prinsesse Ingeborg Halvø (Rugosofusulina arctica Zone) (fig. 2).

\section{Trolle Land Group}

History. This group was erected by Hảkansson (1979) to include the thick sequence of Permo-Triassic siliciclastic sediments overlying the limestone dominated Mallemuk Mountain Group in eastern Peary Land. Here, it is defined to include only the marine part of the sequence forming three major coarsening-upward cycles separated by angular unconformities. Thus, the continental Upper Permian sediments of the Kap Kraka Formation are not included in this group.

Name. After Herluf Trolle Land, eastern Peary Land (fig. 1).

Type area. The north-eastern and eastern slopes of the mountainous area Kim Fjelde (fig. 16).
Fig. 24. Coastal cliffs of Kap Jungersen showing well bedded cliff forming limestones separated by interval of silty limestone (arrow). Cliff height approximately $350 \mathrm{~m}$.

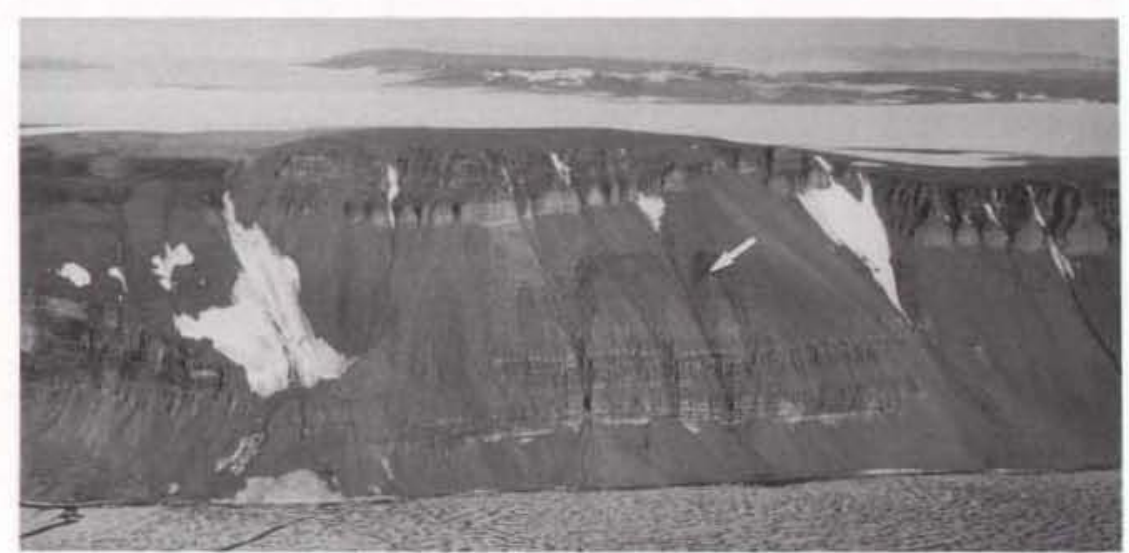




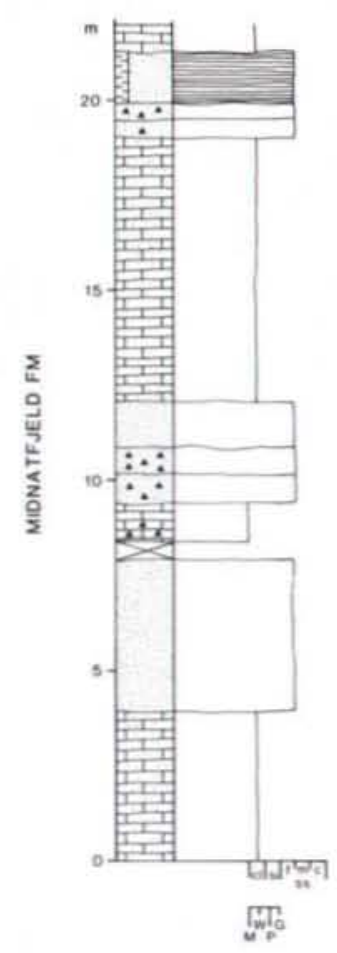

Fig. 25. Sediment log of the uppermost part of the Midnatfjeld Formation in the type section (13).

Thickness. More than $1100 \mathrm{~m}$. However, part of the sedimentation occurred in isolated, fault controlled areas, so the thickest section measured is $600 \mathrm{~m}$.

Dominant lithology. The group is dominated by marine sandstones and shales with subordinate amounts of marine limestones. The sediments are organized in three coarsening upward cycles, each corresponding to a formation.
Boundaries. In eastern Peary Land and on Lockwood $\emptyset$ the group conformably rests on limestones of the Kim Fjelde Formation. It is locally overlain by sediments of the Upper Jurassic - Lower Cretaceous Ladegårdsåen Formation. Elsewhere, the upper boundary is not exposed due to erosion.

Distribution. The group occurs in eastern Peary Land, around Kap Kape and on Lockwood $\emptyset$ (fig. 1).

Geological age. Late Permian (?latest Early Permian) to Middle Triassic (fig. 2).

Subdivisions. The group is divided into the upper Permian Midnatfjeld Formation $(250 \mathrm{~m})$, and the Triassic Parish Bjerg Formation ( $300 \mathrm{~m}$ ) and Dunken Formation (600 m) (fig. 2).

\section{Midnatfjeld Formation}

History. This formation was erected by Håkansson (1979) to include siliciclastic sediments of late Permian age in eastern Peary Land.

Name. After the mountain Midnatfjeld in Kim Fjelde (fig. 16).

Type section. The type section is located in the eastern part of Kim Fjelde (figs 16, 20b, 25).

Reference section. A reference section occurs at the northern slope of Midnatfjeld (fig. 20a).

Thickness. Approximately $300 \mathrm{~m}$ in the type area.

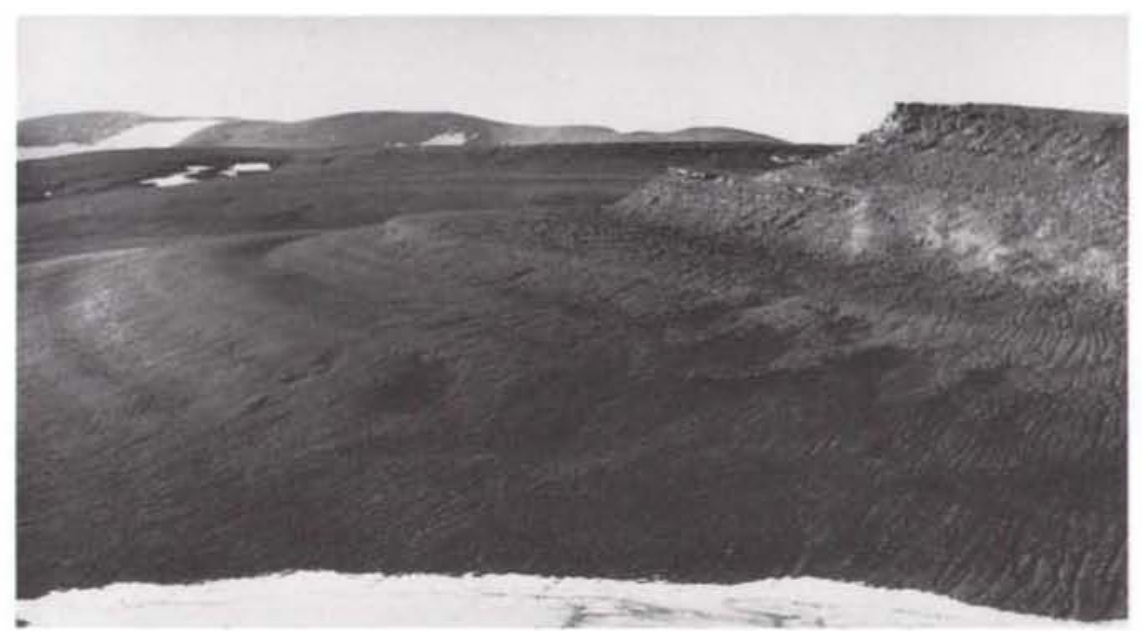

Fig. 26. Interbedded shales and sandstones of the Midnatfjeld Formation at Kim Fjelde. 

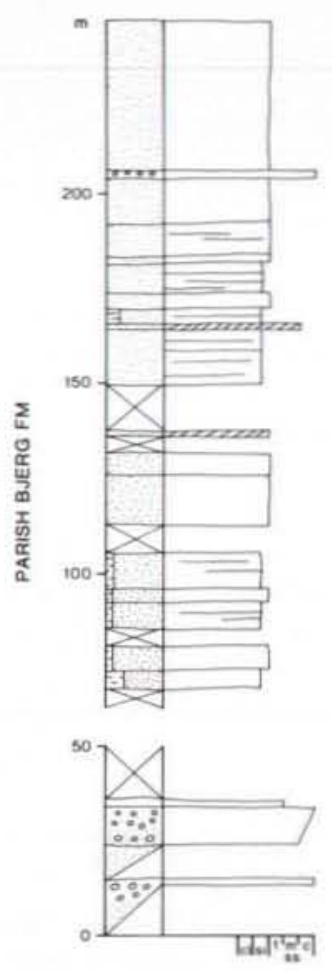

Fig. 27. Sediment log of the Parish Bjerg Formation in the type section (14).

Lithology. The lower part of the formation is dominated by dark calcareous shales containing a sparse marine fauna. The upper part is dominated by fine-grained sandstones, shales and thin limestone beds (fig. 26). Highly diversified marine faunas occur throughout the higher levels.

Boundaries. The formation conformably overlies sediments of the Kim Fjelde Formation. The boundary is placed at the change from limestone and chert dominated lithologies to shale (fig. 20).

The upper boundary is an angular unconformity overlain by sediments of the Triassic Parish Bjerg Formation or locally the Upper Jurassic - Lower Cretaceous Ladegårdsåen Formation (fig. 16).

Distribution. This formation is confined to the northeastern and eastern part of Kim Fjelde (fig. 16).

Age. Late Permian, possibly ranging down into the latest Early Permian (fig. 2).

\section{Parish Bjerg Formation}

History. This formation was erected by Håkansson (1979) to comprise a series of sandstones, shales and conglomerates separated from the Midnatfjeld Formation by a slight angular unconformity.

Name. After the mountain Henry Parish Bjerg in Kim Fjelde (fig. 19).

Type section. The type section (14) is at the north-west slope of Henry Parish Bjerg (figs 16, 27, 28).

Thickness. The formation is $340 \mathrm{~m}$ thick in the type section. In fault-blocks where the formation is unconformably overlain by the Ladegårdsåen Formation only the basal part of the formation is preserved.

Lithology. The lower part of the formation consists of reddish weathering sandstones alternating with pebbly conglomerates (figs 27, 29). Planar cross-bedding and ripple cross-bedding are common in this part. Above follow poorly exposed heterolithic shales and the upper
Fig. 28. The mountain Henry Parish Bjerg showing location of section 14

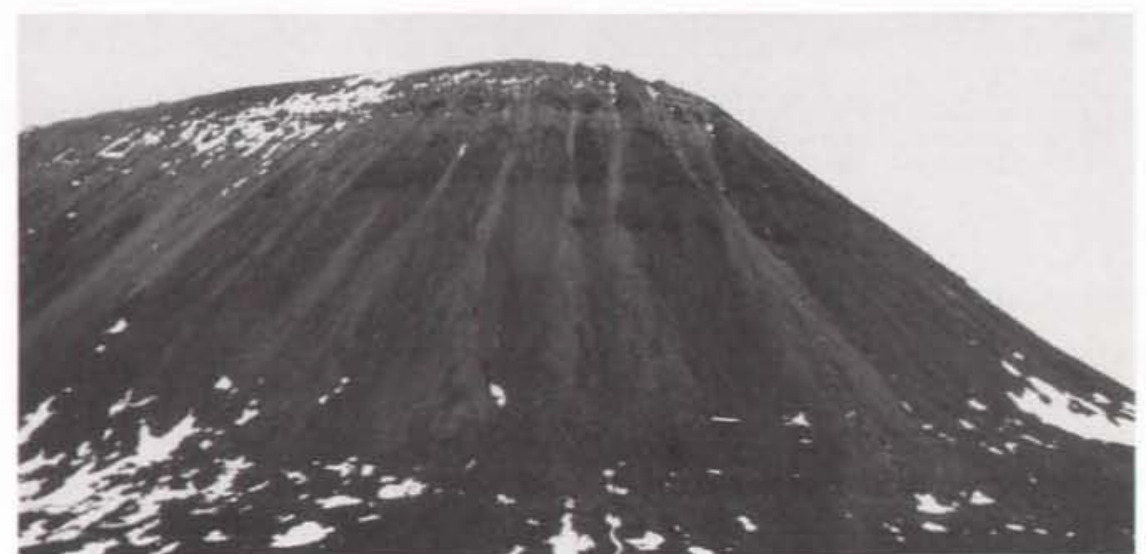




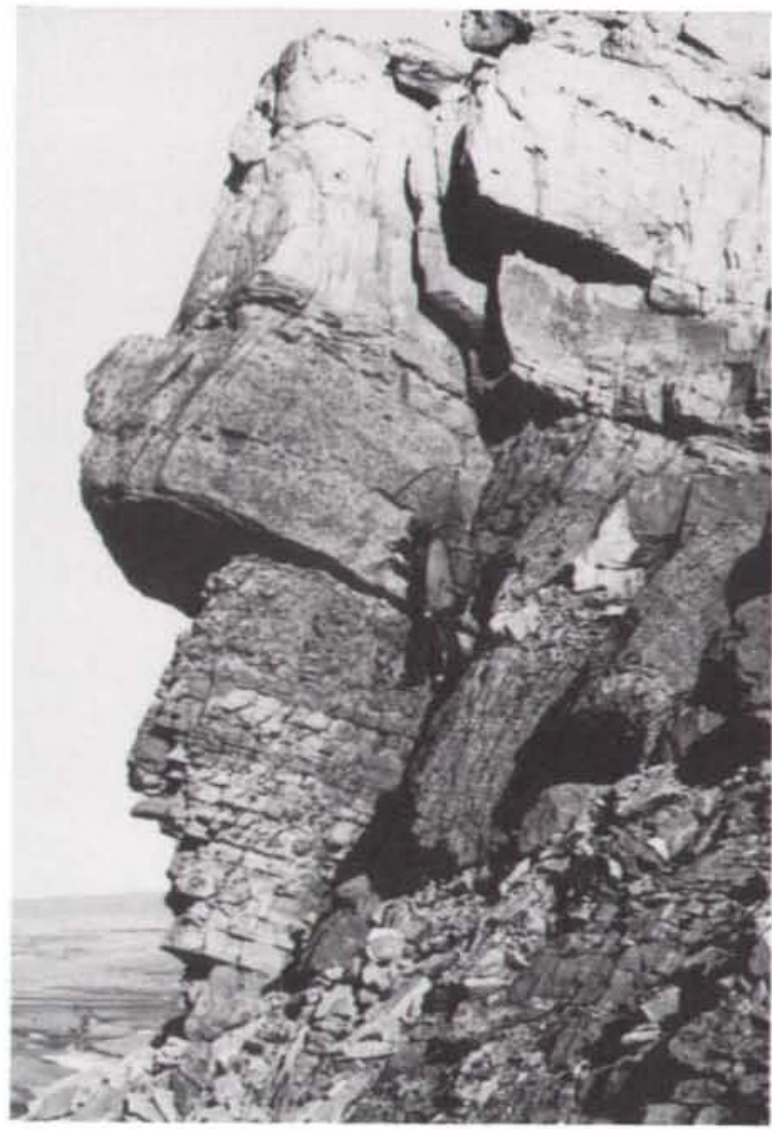

part of the formation is dominated by fine-grained sandstone. Well preserved trace fossils, e.g. Rhizocorallium, indicate shallow marine conditions during deposition of the upper sandy part.

Boundaries. The lower boundary is a slight angular unconformity separating the formation from the underlying Midnatfjeld Formation. Also the upper boundary is an angular unconformity to the Upper Jurassic Lower Cretaceous Ladegårdsåen Formation (fig. 16).

Distribution. The formation is confined to the eastern parts of Kim Fjelde.

Age. Poorly dated, most likely Triassic throughout.

\section{Dunken Formation}

History. This name was given by Håkansson (1979) to a thick Triassic sequence of mainly sandstones and shales restricted to an isolated fault block in the eastern part of Kim Fjelde. The formation corresponds in part to the Triassic sections of Troelsen (in Kummel, 1953).
Fig. 29. Pebble conglomerates and sandstones of the basal part of Parish Bjerg Formation at Kim Fjelde. Geologist for scale.

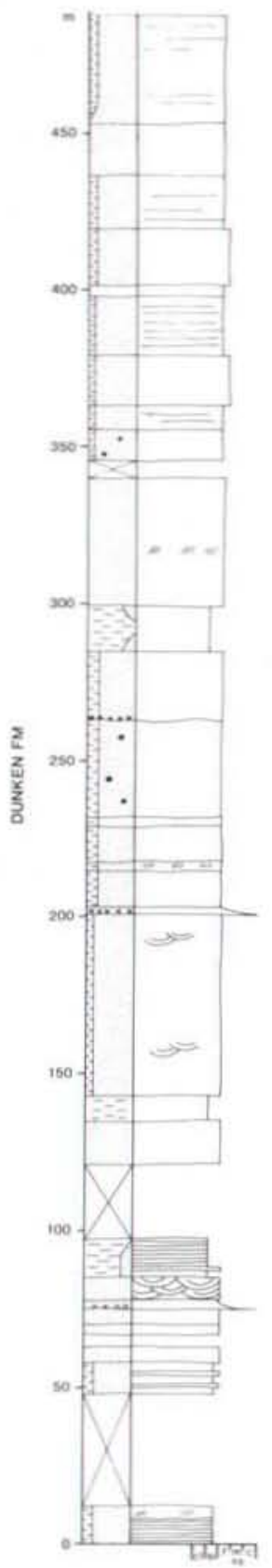

Fig. 30. Sediment log of the Dunken Formation in the type section (15). 
Fig. 31. The mountain Dunken showing position of section 15 .

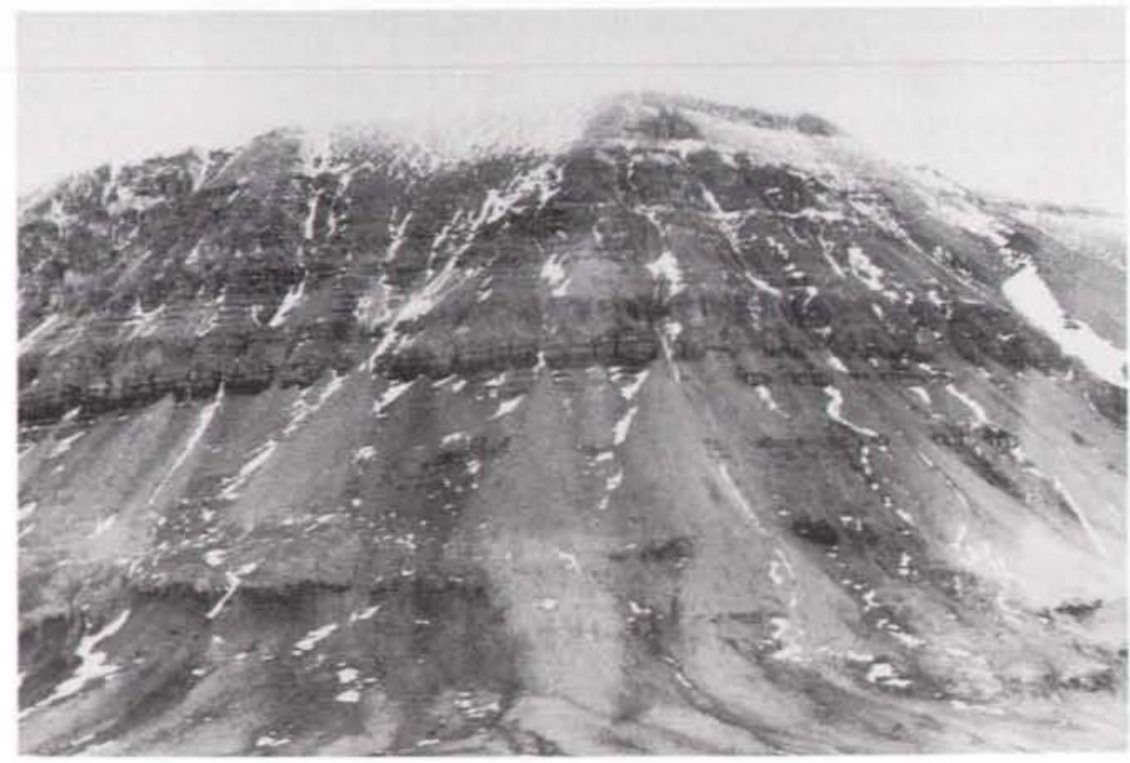

Name. After the mountain Dunken in the eastern part of Kim Fjelde (fig. 19).

Type sections. The type section (15) is from the northern slope of Dunken (figs 30, 31).

Thickness. A $500 \mathrm{~m}$ thick section has been measured at the type locality. Hankansson (1979) estimated the total thickness at the type locality to be approximately $600 \mathrm{~m}$ which is in accordance with the thickness of a section measured by Troelsen (in Kummel, 1953).

Lithology. The lower part of the formation is dominated by marine, greyish-black shales containing abundant fossils (Troelsen in Kummel, 1953). The upper part of the formation is dominated by yellow weathering, fine to medium grained sandstones. Bedding is irregular and cross-bedding occurs only rarely. Marine fossils are restricted to phosphatic nodules in a $20-30 \mathrm{~m}$ thick interval (fig. 30), but marine trace fossils, mainly Rhizocorallium, occur throughout the sandy part. Therefore, Hăkansson \& Heinberg (1977) concluded that the entire formation represents a fully marine environment.

Boundaries. Neither the lower nor the upper boundary is known.
Fig. 32. The type locality of the Kap Kraka Formation showing the fault bound Permian sediments (P). Photo: A. K. Higgins.

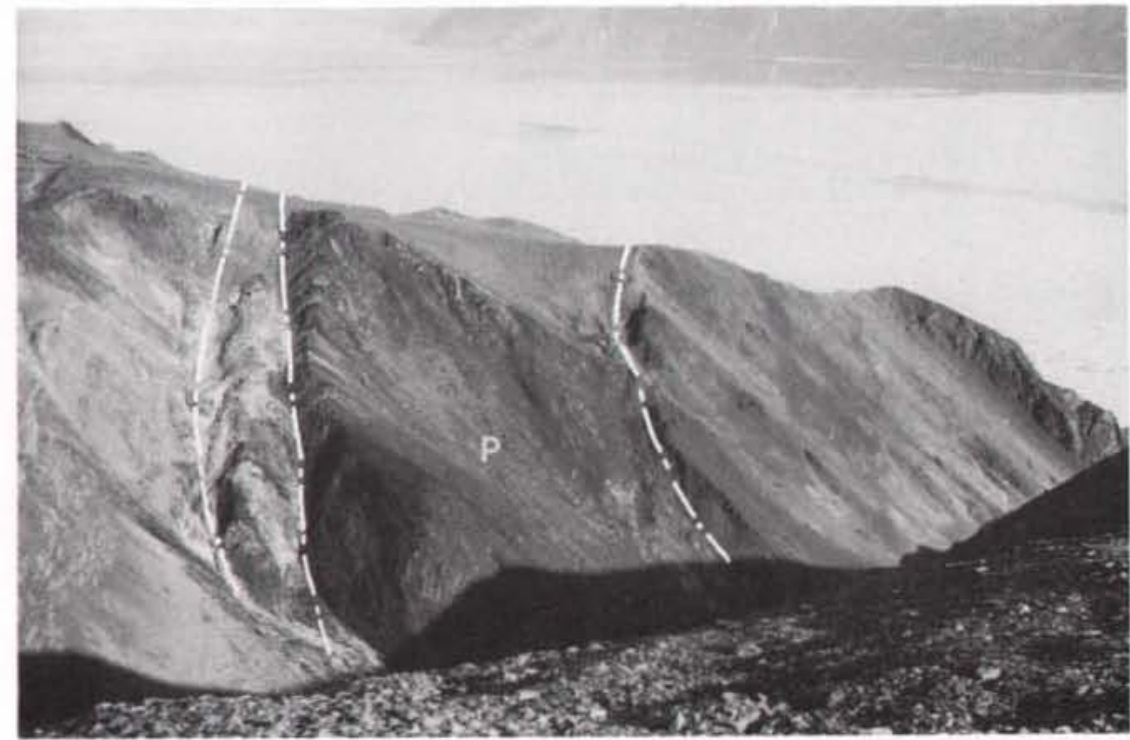


Distribution. The formation is confined to an isolated fault block in eastern Kim Fjelde (fig. 16).

Age. Early - Middle Triassic, the lower shaly part is of Scythian age and the sandy part is of Anisian age but the top half of the formation remains undated.

\section{Kap Kraka Formation}

new formation

History and definition. This formation is erected to include the Upper Permian sediments described by Soper et al. (1980), Håkansson et al. (1981) and Wagner et al. (1982) from the Harder Fjord Fault Zone at a location near Midtkap (figs 1, 32).

Name. After Kap Kraka in the central part of Frederick E. Hyde Fjord (fig. 1).

Type section. Not available.

Thickness. Estimated to be approximately $400 \mathrm{~m}$.

Lithology. The formation comprises sandstones, conglomerates and silty to coaly shales with abundant impressions of plants (fig. 33).

Boundaries. Both the upper and the lower boundaries are unknown (Hăkansson et al., 1981; Wagner et al., 1982).

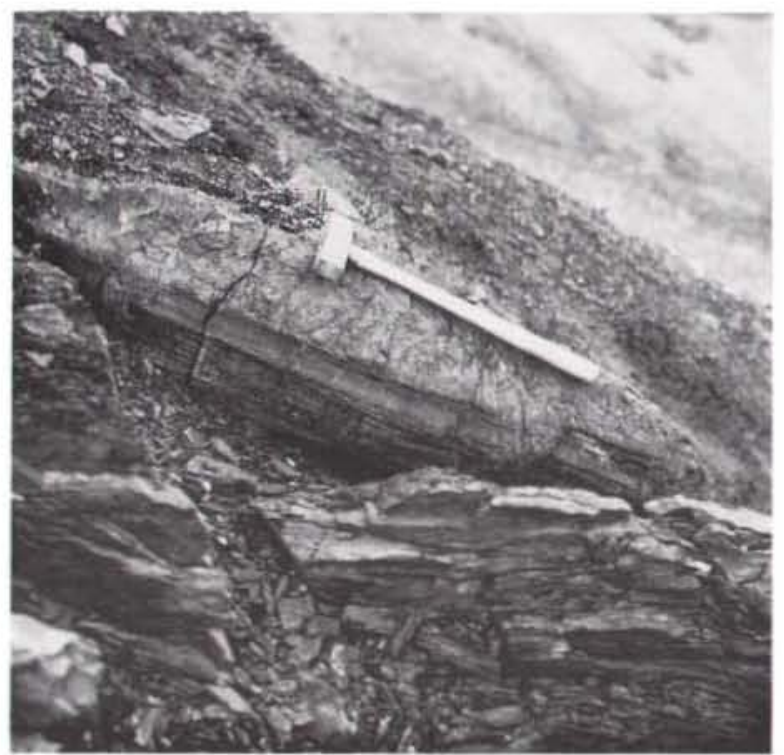

Fig. 33. Tree trunk in hematitic sandstone. Kap Kraka Formation. Photo: A. K. Higgins.
Distribution. The formation is confined to small, faultbounded areas near Midtkap (figs 19, 32).

Age. Late Permian.

\section{Depositional history}

The depositional history of the Upper Palaeozoic Triassic sequence in eastern North Greenland described briefly by Håkansson \& Stemmerik (1984) is summarized below. During Late Palaeozoic times there appears to be good correlation between North Greenland and both Svalbard and the Sverdrup Basin (e.g. Hãkansson \& Stemmerik, 1984; Steel \& Worsley, 1984; Davies \& Nassichuk, in press). However, compared with these two areas the North Greenland succession is much less complete as only sediments from a narrow part of the platform are preserved.

Early Carboniferous (? Visean). Prior to the early Moscovian transgression a thick sequence of fluviatile sediments was deposited on the southern Holm Land block (fig. 34A). Thus, more than $600 \mathrm{~m}$ thick sequence consists of stacked fining upward cycles of flood-plain origin (Håkansson \& Stemmerik, 1984). A low angle internal unconformity divides the sequence into a lower sandy unit and an upper shaly unit.

Early Moscovian. During early Moscovian (Profusulinella zone) times the sea transgressed the southern Holm Land and southern Amdrup Land blocks (fig. 34B). Prior to the transgression the Lower Carboniferous sediments were disturbed along $\mathrm{N}-\mathrm{S}$ trending faults and subsequently eroded creating considerable relief.

The margin of the basin was dominated by coarse clastic sediments deposited in a shallow marine environment. Further to the east in southern Holm Land (fig. 34B) cyclically interbedded sandstone and biogenic limestone were deposited in alternating high energy, siliciclastic dominated and more quiet, limestone dominated shelf environments.

The shelf sediments prograded gradually towards the west, and during late Early Moscovian times coarse siliciclastic sedimentation appears confined to the western marginal areas (fig. 34C). A wide, shallow carbonate shelf then covered most of southern Holm Land (fig. $34 \mathrm{C})$. At the same time carbonate sedimentation was restricted in Amdrup Land to a narrow 1-2 km wide, $\mathrm{N}-\mathrm{S}$ trending zone (fig. $34 \mathrm{C}$ ). The carbonate platform developed here with as much as $50 \mathrm{~m}$ of relief to the surrounding basins which gradually became filled by black shale and thin interbeds of gypsum (fig. 13). 

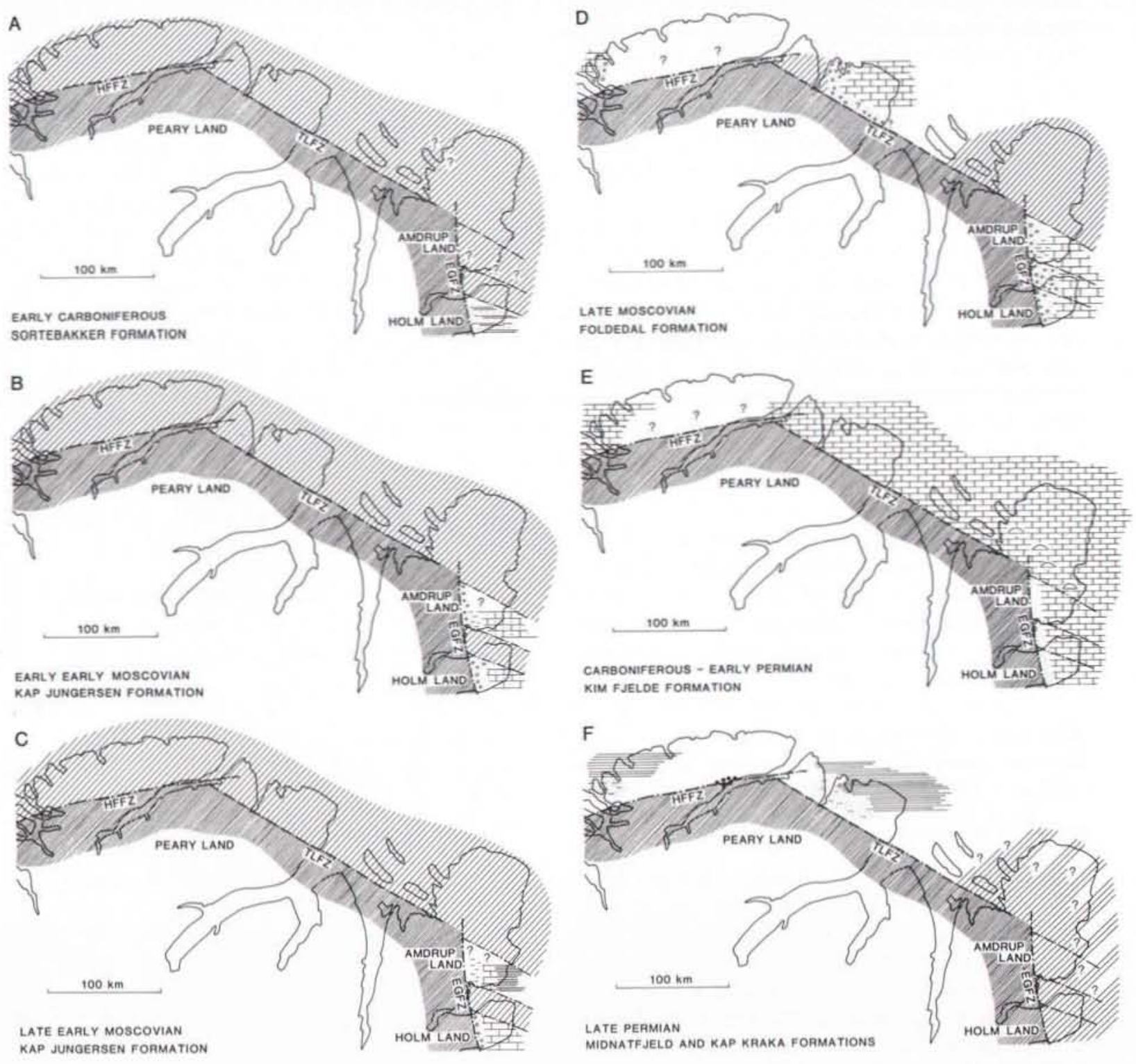

MIDNATF JELD AND KAP KAAKA FORMATIONS

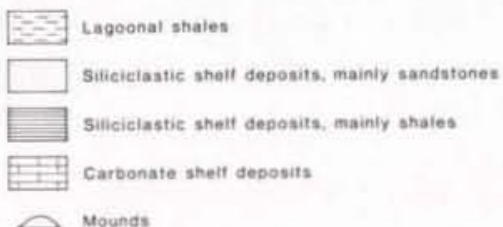

Fig. 34. Palaeogeographic maps and facies patterns during Carboniferous to Permian time. 
Late Moscovian - Gzhelian. During the late Moscovian (Wedekindellina zone) a new transgression reached northern Holm Land and Peary Land in addition to the former transgressed areas (fig. 34D). Considerable influx of coarse siliciclastic material (fig. 34D) suggests that this event was partly related to movements along the fault zones.

Gradually the siliciclastic supply decreased and alternating biogenic limestones and marine sandstones deposited in widespread shelf environments (fig. 34D).

Late Carboniferous - Early Permian (Kungurian). During Late Carboniferous time (Triticites zone) the reduced relief of the land areas gave rise to widespread deposition of shelf carbonates. The ongoing transgression reached northern Amdrup Land, Kronprins Christian Land and the western part of eastern Peary Land early in the Permian (Rugosofusulina zone) and during the remaining part of the Early Permian bedded biogenic limestones were deposited throughout the area (fig. 34E).

Late Permian. The depositional pattern changed drastically in the latest Early Permian or earliest Late Permian (fig. 34F). Renewed tectonic activity along the Harder Fjord Fault Zone is indicated by deposition of thick wedges of continentally derived conglomerates. The shelf areas became the site of clastic deposition (fig. 34F). Initially, deep water shales and cherts dominated, but towards the end of the Permian shallow marine sandstones prograded across the shelf as the consequence of the ongoing regression that finally exposed the area in the lastest Permian.

Triassic. In Triassic times sedimentation was initiated by deposition of reddish pebble conglomerates in a proposed nearshore setting. The remaining part of the Triassic history in North Greenland is dominated by two episodes of basin deepening and mud deposition followed by sandstone progradation and infill. The two resulting coarsening upward sequences correspond to the Parish Bjerg and Dunken Formations.

The very limited present-day outcrop of Triassic sediments leaves no clues to the original extent of the Triassic basin in North Greenland.

Acknowledgements. The field work forming the basis of this report was undertaken during the Geological Survey of Greenland's three-year activity in central and eastern North Greenland in 1978-1980. We would like to thank N. Henriksen for organising all logistical aspects of this field work, and P. Molgaard and C. Heinberg for good company in the field. Dis- cussions concerning various aspects of Carboniferous to Triassic stratigraphy with S. Piasecki are gratefully acknowledged. Finally, we thank J. Halskov, B. Sikker Hansen, M. Larsen and J. Lautrup for technical assistance.

\section{References}

Bendix-Almgreen, S. E. 1975: Fossil fishes from the marine Late Paleozoic of Holm Land - Amdrup Land. Meddr Gronland 195(9), $38 \mathrm{pp}$.

Bengaard, H.-J. \& Henriksen, N. 1986: Geologisk kort over Grenland, 1:500 000, Sheet 8, Peary Land. Copenhagen: Grønlands Geologiske Undersøgelse.

Būtler, H. 1961: Continental Carboniferous and Lower Permian in Central Greenland. In Raasch, G. O. (edit.) Geology of the Arctic 1, 205-213. University of Toronto Press.

Cutbill, J. L. \& Challinor, A. 1965: Revision of the stratigraphical scheme for the Carboniferous and Permian of Spitsbergen and Bjørnøya. Geol. Mag. 102, 418-439.

Davies, G. R. \& Nassichuk, W. W. in press: Carboniferous and Permian history of the Sverdrup Basin, Arctic Islands. In Trettin, H. P. (edit.) The Innuitian region. The geology of North America E. Ottawa: Geol. Surv. Canada.

Dawes, P. R. 1976: Precambrian to Tertiary of northern Greenland. In Escher, A. \& Watt, W. S. (edit.) Geology of Greenland, 249-303. Copenhagen: Geol. Surv. Greenland.

Dawes, P. R. \& Soper, N. J. 1973: Pre-Quaternary history of North Greenland. In Pitcher, M. G. (edit.) Arctic geology. Mem. Amer. Ass. Petrol. Geol. 19, 117-134.

Dunbar, C. O. 1962: Faunas and correlation of the Late Paleozoic rocks of northeast Greenland. Part III. Brachiopoda. Meddr Gronland 167(6), 14 pp.

Dunbar, C. O., Troeisen, J., Ross, C., Ross, J. P. \& Norford, B. 1962: Faunas and correlation of the Late Paleozoic rocks of northeast Greenland. Part I. General discussion and summary. Meddr Grønland 167(4), 16 pp.

Frebold, H. 1950: Stratigraphie und Brachiopodenfauna des marinen Jungpalaeozoikums von Holms und Amdrups Land (Nordostgrönland). Meddr Gronland 126(3), $97 \mathrm{pp.}$

Grönwall, K. G. 1916: The marine Carboniferous of NorthEast Greenland and its brachiopod fauna. Meddr Gronland 43(20), $110 \mathrm{pp.}$

Hăkansson, E. 1979: Carboniferous to Tertiary development of the Wandel Sea Basin, eastern North Greenland. Rapp. Gronlands geol. Unders. 88, 72-83.

Hákansson. E. \& Heinberg, C. 1977: Reconnaissance work in the Triassic of the Wandel Sea Basin. Peary Land, eastern North Greenland. Rapp. Gronlands geol. Unders, 85, 11-15.

Hãkansson, E., Heinberg, C. \& Stemmerik, L. 1981: The Wandel Sea Basin from Holm Land to Lockwood $\emptyset$. eastern North Greenland. Rapp. Gronlands geol. Unders. 106. 47-63.

Hákansson, E. \& Stemmerik, L. 1984: Wandel Sea Basin - The North Greenland equivalent to Svalbard and the Barents Shelf. In Spencer, A. M. et al. (edit.) Petroleum geology of 
the North European margin, 97-107. Graham \& Trotman for the Norwegian Petroleum Society.

Halle, T. G. 1931: Younger Palaeozoic plants from East Greenland. Meddr Grønland 85(1), 26 pp.

Halle, T. G. 1953: The Carboniferous flora of East Greenland. Proc. 7th int. bot. Congr. Stockh. 1950, 594-595.

Henriksen, N. 1981: Systematic geological mapping in the Peary Land - Kronprins Christian Land region, North Greenland. Rapp. Grønlands geol. Unders. 106, 5-6.

Koch, L. 1923: Preliminary report upon the geology of Peary Land, Arctic Greenland. Am. J. Sci. (5) 5, 189-199.

Koch, L. 1925: The geology of North Greenland. Am. J. Sci. (5) 9, 271-285.

Koch, L. 1929: Stratigraphy of Greenland. Meddr Grønland 73(2), $116 \mathrm{pp}$.

Kummel, B. 1953: Middle Triassic ammonites from Peary Land. Meddr Grønland 127(1), 21 pp.

Nathorst, A. G. 1911: Contributions to the Carboniferous flora of Northeastern Greenland. Meddr Grønland 43(12), $10 \mathrm{pp}$.

Nielsen, E. 1941: Remarks on the map and geology of Kronprins Christian Land. Meddr Grønland 126(2), 34 pp.

Peel, J. S., Dawes, P. R. \& Troelsen, J. C. 1974: Notes on some Lower Palacozoic to Tertiary faunas from eastern North Greenland. Rapp. Grønlands geol. Unders. 65, 18-23.

Petryk, A. A. 1977: Upper Carboniferous (Late Pennsylvanian) microfossils from the Wandel Sea Basin, Peary Land, eastern North Greenland. Rapp. Grønlands geol. Unders. 85, 16-21.
Ross, C. A. \& Dunbar, C. O. 1962: Faunas and correlation of the Late Paleozoic rocks of northeast Greenland. Part II. Fusulinidae. Meddr Grønland 167(5), $55 \mathrm{pp}$.

Ross, J. P. \& Ross, C. A. 1962: Faunas and correlation of the Late Paleozoic rocks of northeast Greenland. Part IV. Bryozoa. Meddr Grønland 167(7), 65 pp.

Soper, N. J., Higgins, A. K. \& Friederichsen, J. D. 1980: The North Greenland fold belt in eastern Johannes V. Jensen Land. Rapp. Grønlands geol. Unders. 99, 89-98.

Steel, R. J. \& Worsley, D. 1984: Svalbards post-Caledonian strata - an atlas of sedimentational patterns and palaeographic evolution. In Spencer, A. M. et al. (edit.) Petroleum geology of the North European margin, 109-135. Graham \& Trotman for the Norwegian Petroleum Society.

Stemmerik, L. 1989a: Crinoid - bryozoan reef mounds, Upper Carboniferous, Amdrup Land, eastern North Greenland. In Geldsetzer, H. (edit.) Reef case histories. Can. Soc. Petrol. Geol. Mem. 13, 690-694.

Stemmerik, L. 1989b: Chaetetid bioherm, Upper Carboniferous, Holm Land, eastern North Greenland. In Geldsetzer, H. (edit.) Reef case histories. Can. Soc. Petrol. Geol. Mem. 13, 688-689.

Troelsen, J. 1950: Geology. In Winther, P. C. et al. A preliminary account of the Danish Pearyland Expedition, 1948-9. Arctic 3, 6-8.

Wagner, R. H., Soper, N. J. \& Higgins, A. K. 1982: A Late Permian flora of Pechora affinity in North Greenland. Rapp. Grønlands geol. Unders. 108, 5-13. 